\title{
U1 norden
}

Norræna rádherranefndin

AF STAD MED

ÚRGANUGSFORVARIUIR

\section{NEMENDAHEFTI}

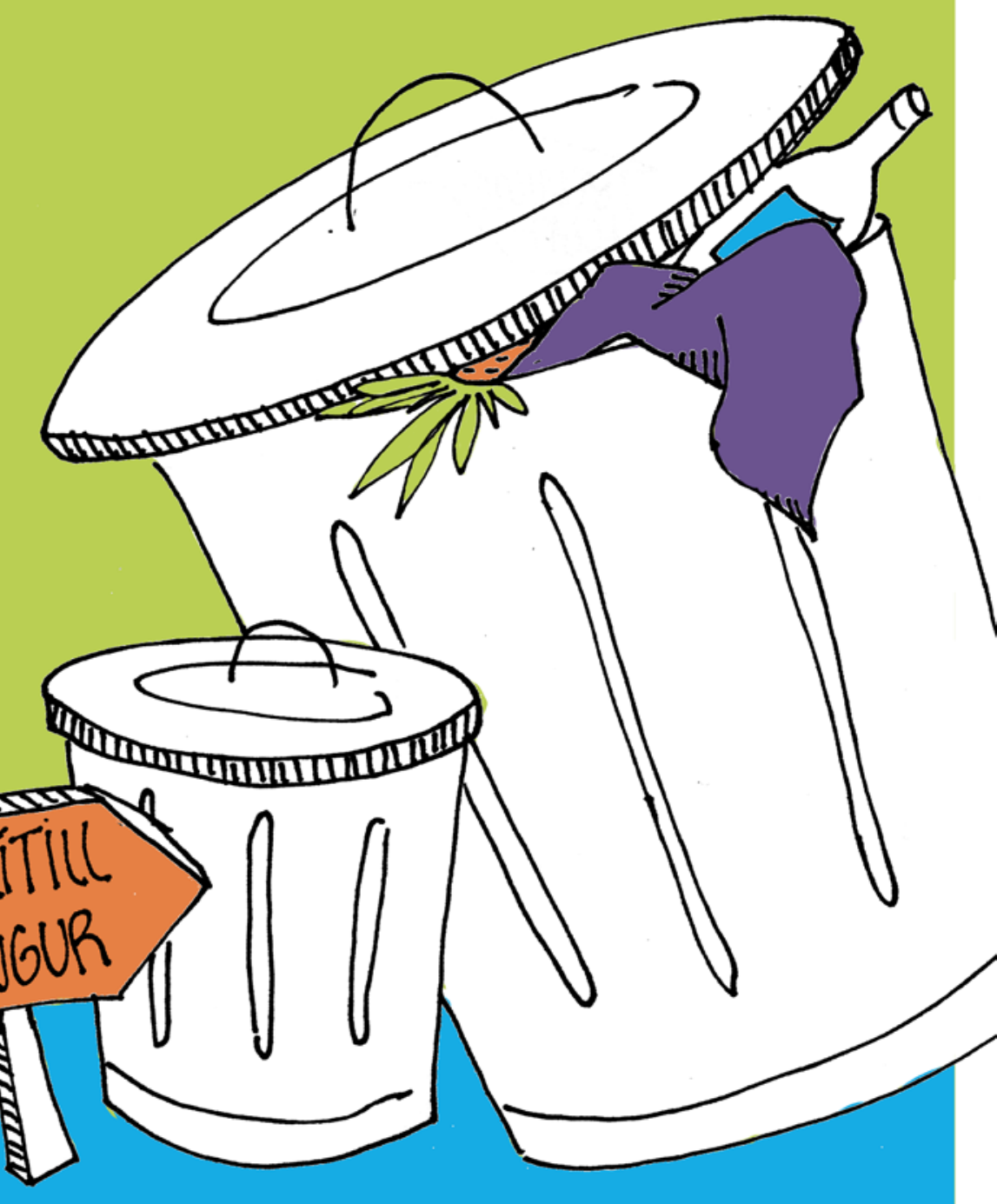




\section{EFNISYFIRLIT}

\section{ÚRGAUGSFORVAROUIR}

VERKEFNI 1 Aðföng og hráefni til glergerðar 6

VERKEFN 2 Hvað eru úrgangsforvarnir? 10

\section{FATIUAOUR}

VERKEFNI 3 Hvernig er stuttermabolur framleiddur? 16

VERKEFNI 4 Hvernig lengjum við líftíma fatnaðar? 19

VERKEFNI 5 Finnið ykkur viðfangsefni 21

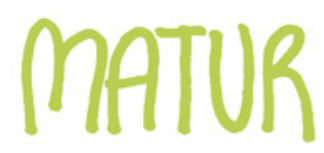

VERKEFNI 6 Hvenær fleygjum við mat? 26

VERKEFNI 7 Hve miklum mat er fleygt í matvöruverslunum? 28

\section{RAFEINDATTEKI}

VERKEFN 8 Kannið hvaða efni eru í rafeindatækjum og hvað verður um pau að notkun lokinni 34

VERKEFNI 9 Hvernig getum við fyrirbyggt myndun úrgangs við notkun rafeindatækja? 38 


\section{HEIL OG SAL}

Hefur pú velt pví fyrir pér hverju pú fleygir í ruslið? Og hvað heldur pú að úrgangurinn sé mikill á einu ári?

Ef við gerum ráð fyrir pví að við fleygjum um 2 kg í ruslafötuna daglega alla 365 daga ársins, getum við reiknað út að hver og einn fleygir u.p.b. 730 kg í ruslið árlega. Petta verður mikill úrgangur pegar við erum mörg, t.d. allir nemendur í einum bekk.

Gætum við notað eitthvað af pessu aftur eða á annan hátt?

Í pessu hefti er að finna fjölda skemmtilegra verkefna sem fjalla um hvernig við getum komið í veg fyrir myndun úrgangs frá fatnaði, mat og rafeindatækjum.

Góða skemmtun!

\section{Norraena ráăherranefindin}




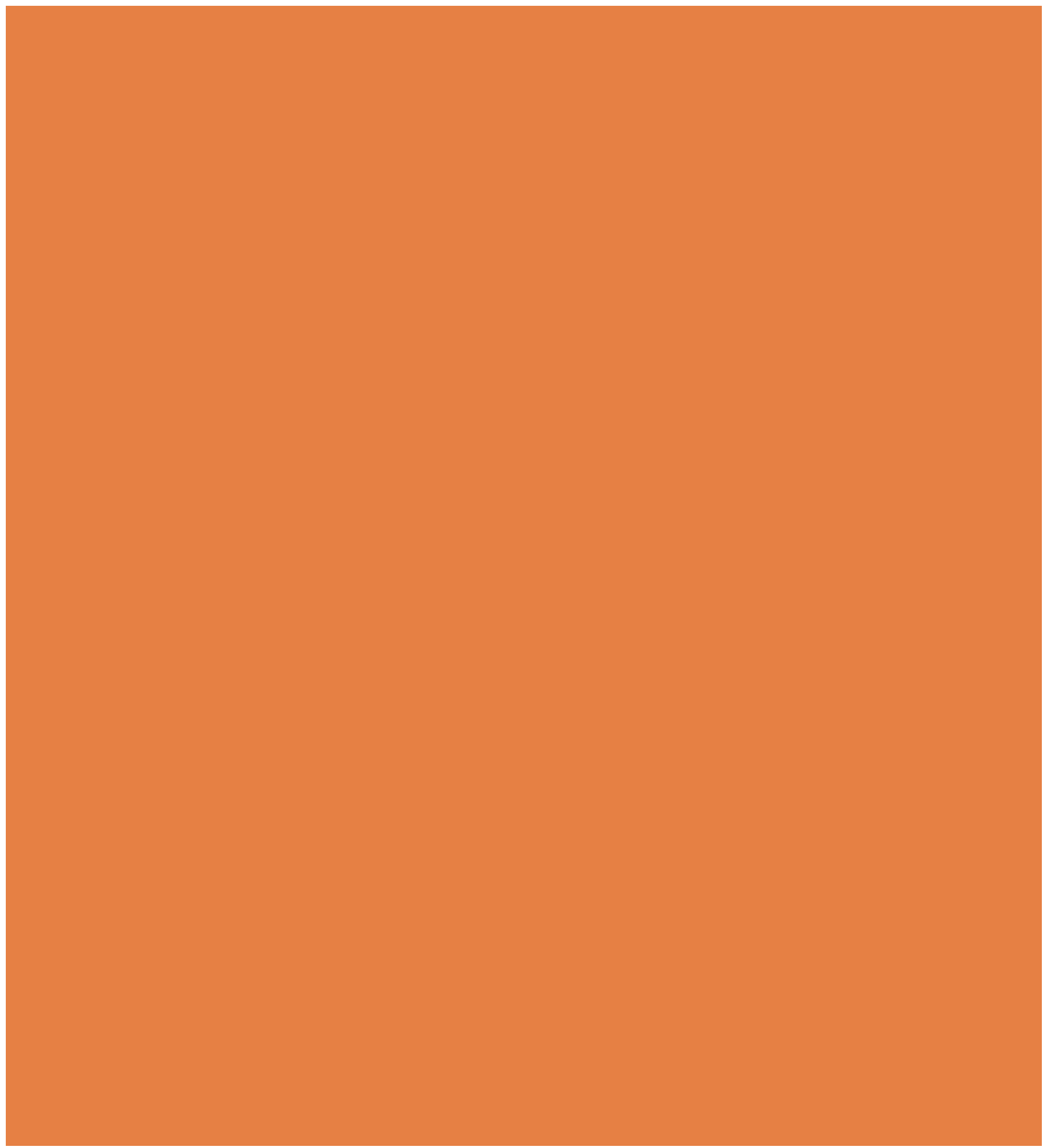




\section{URGANGGSORVARTUIR}

VERKEFNI 1

VERKEFNI 2 


\section{VERKEFNI 1}

\section{AĐFÖNG OG HRÁEFNI TIL GLERGERĐAR}

\section{INNGANGUR}

Pegar við kaupum sultukrukku purfum við að átta

okkur á pví að ýmis aðföng parf til sultugerðar.

Einnig parf margvísleg hráefni í glerkrukkuna sem sultan er í.

Auðlindir er orð sem notað er um aðföng og hráefni sem nota parf til að framleiða ýmsa hluti. Í alla hluti sem við höfum í kring um okkur parf auðlindir.

Jörðin gefur af sér næstum allar auðlindir okkar. Sumar auðlindir geta endurnýjast. Við getum til dæmis gróðursett berjarunna og nýtt berin í sultu.

En til eru auðlindir sem ekki endurnýjast eða parfnast mikillar orku. Petta á t.d. við um sand sem notaður er til glergerðar eða málma sem parf til að framleiða lok á sultukrukkuna.

\section{VERKEFNI}

Skoðið notaða sultukrukku eða líkt ílát með loki. Athugið úr hvaða efnum lokið og sultukrukkan er gerð.

\section{Ræðið í vinnuhópnum ykkar:}

Hvaða eiginleika hafa pessir hlutir? Eru peir til dæmis harðir, mjúkir, gegnsæir, endingargóðir, vatnspéttir, loftpéttir, auðvelt að prenta á, auðvelt að opna og auðvelt að loka.
> Hver er ástæðan fyrir vali á efnum sem notuð eru við krukkugerðina?

$>$ Væri hægt að nota önnur efni?

$>$ Af hverju haldið pið аð efnisvalið sé eins og raun ber vitni?

$>$ Hvernig finnst ykkur krukkan og umbúðirnar nýtast undir pað sem var í krukkunni?

> Hvað er pýðingarmikið fyrir verksmiðjuna sem framleiðir afurðina?

> Hvað skiptir máli fyrir matvöruverslunina eða kaupmanninn sem selur afurðina?

$>$ Hvað finnst pér skipta máli pegar pú parft að velja milli sömu vöru í mismunandi umbúðum?

$>$ Reyndu að komast að pví hvaðan efnið er upprunnið sem notað er við framleiðslu á glerkrukku og loki.

Athugið hvort hægt er að endurnýta pessa hluti. Skrifið niðurstöðuna í tvo dálka: efni sem hægt er að endurvinna og efni sem ekki er hægt að endurvinna.

Reynið að gera ykkur í hugarlund pær auðlindir sem nýttar hafa verið í öllu ferlinu við að framleiða krukku og lok.

Í gamla daga geymdu margir svona krukkur og notuðu undir heimalagaða sultu eða eitt og annað sem útbúið var í eldhúsinu.

$>$ Eru krukkur ennpá notaðar á pennan hátt?

$>$ Hvað er gert á pínu heimili við svona glerkrukkur? 


\section{NOTA OG FLEYGTA LIESSTILL}

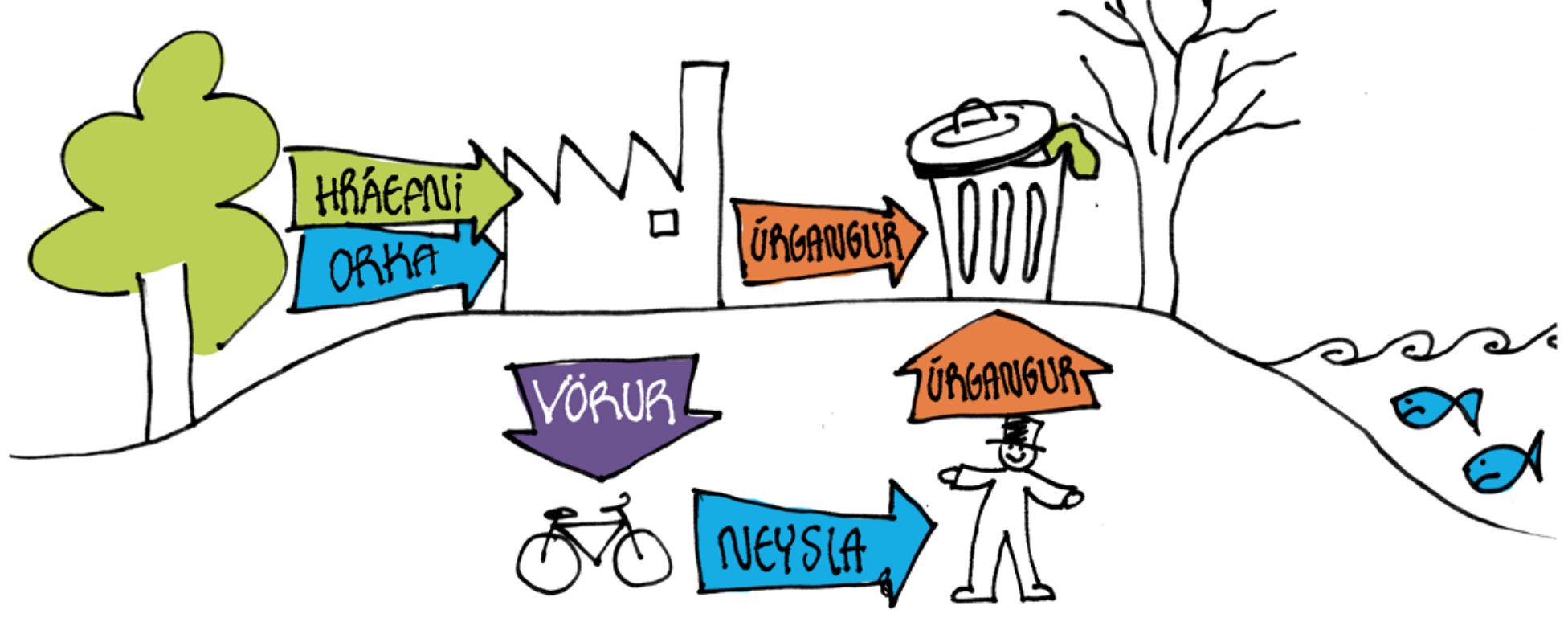

Ræəið saman í bekknum um:

$>$ Hvað finnst ykkur henta að nota undir sultu, síld, hnetusmjör o.fl.

$>$ Hafið pið tillögur um hvernig við getum endurnýtt pessar glerkrukkur betur?

> Hvað finnst pér mikilvægt að gera ef sífellt meira berst af glerkrukkum frá hverju heimili?

$>$ Geta framleiðendur gert eitthvað til pess að draga úr álagi á umhverfið pegar framleiðslan á sér stað?

$>$ Getum við sem kaupum pessa vöru gert eitthvað til að koma í veg fyrir vanda sem hlýst af framleiðslu, neyslu og úrgangi?

Hafið pið tillögur um hvernig hægt er að nota úrgang sem auðlind til að framleiða úr nýja hluti? pið getið byrjað á að hugsa um endurvinnslu á sultukrukku sem pið hafið skoðað.

\section{VEIST PÚ?}

Að ef við höldum áfram að nota hluti í stórum stíl og fleygjum peim í ruslið, pá eykst úrgangur bæði hjá okkur og par sem hlutirnir eru framleiddir.

\section{HEFUR PÚ HUGLEITT?}

Margir hafa gert pað að lífstíl sínum að kaupa sífellt og nota nýja hluti. Petta háttarlag getum við kallað; ;, nota og fleygja" lífsstíl. 


\section{STÁLBBERR NUEYSLA}

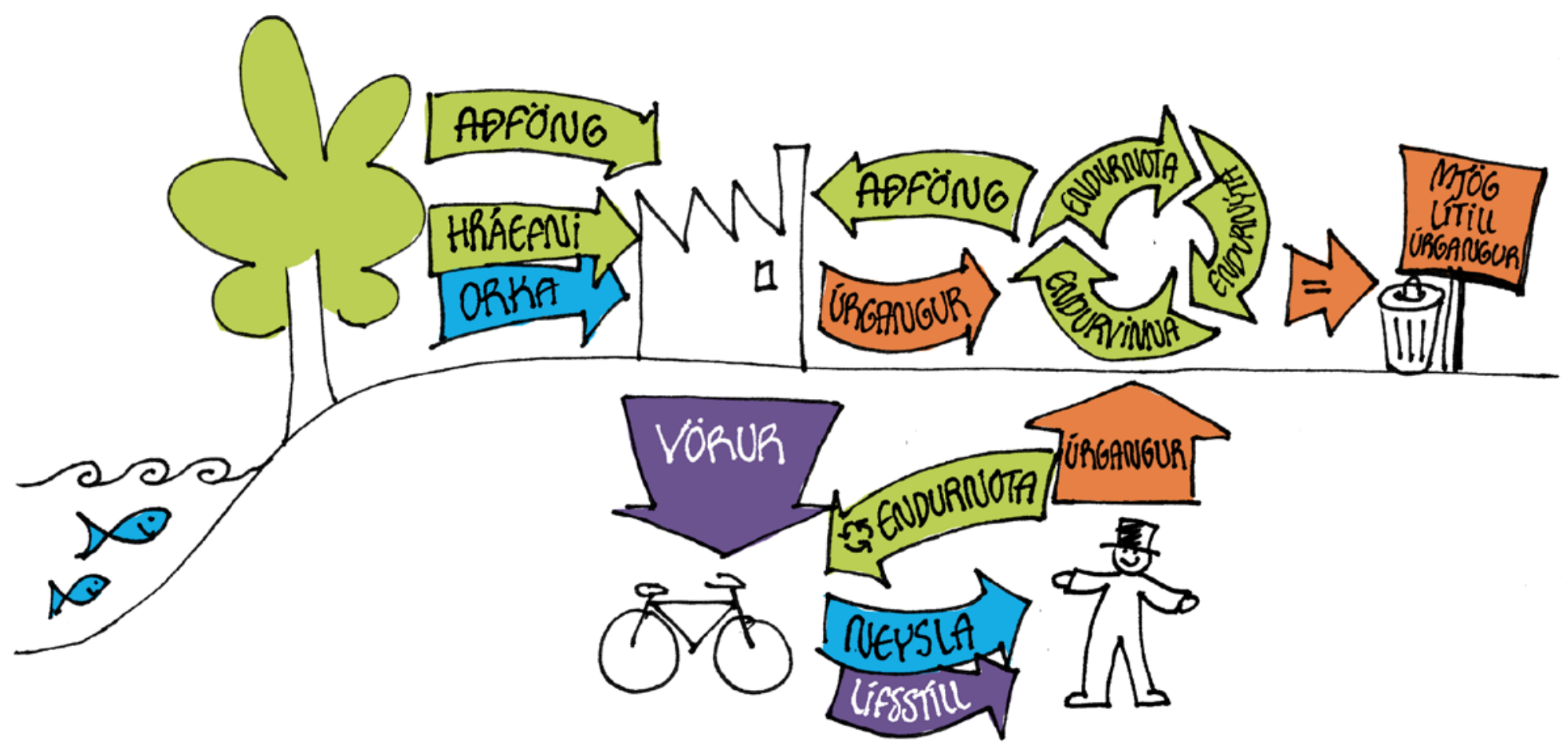

\section{VISSIR PÚ?}

\section{Sjálfbærni pýðir meðal annars}

$>$ að við spörum vatn og orku

$>$ að úrgangur verður eins lítill og unnt er

$>$ að við völdum sem minnstum skaða á náttúru og umhverfi.

\section{VISSIR PÚ?}

Hægt er að framleiða nýtt reiðhjól úr áli úr 670 áldósum undan gosdrykkjum.

\section{HEFUR PÚ HUGLEITT?}

Miklu af peim úrgangi sem er fleygt, er hægt að̌ nýta aftur. 


\section{HRÁEFNI}

Hráefni eru náttúruafurðir sem notaðar eru í vörur og matvæli.

Hráefni eru líka auðlindir.

Við notum hráefni til að framleiða ýmsan varning.

Plast er til dæmis unnið úr olíu.

Fjöldi hráefna eru óendurnýjanleg og ekki hægt að endurgera. Olía myndast á mjög löngum tíma. Sú olía sem unnin er í dag hefur verið neðanjarðar í margar milljónir ára!

\section{AUDLINDIR}

Auð̌lindir samanstanda af fjölda náttúruafurða og hráefna sem eru til ráđstöfunar og hægt er að hagnýta. Petta geta verið jarðefni en einnig tré eða úrgangur, svo fremi að við getum notað efnið eða afurð̋ina aftur.

Ein er sú auð̌lind sem við getum endurnýtt, en pað eru glerkrukkur, glerflöskur og annað glerkyns sem við hendum í glersöfnunarilát. Úr pessum úrgangi er hægt að̃ framleiōa nýjar krukkur og flöskur. Á Íslandi er mulið gler notað̃ sem millilag á urðunarstöðum og í litlum mæli í malbik. Listamenn nýta margskonar glerafurðir við listsköpun.

Til að framleiða gler parf sand sem hráefni. Steinull er í senn hljóðeinangrun, varmaeinangrun og brunaeinangrun. Sandur er hráefni í steinull.

\section{VISSIR PÚ?}

Ef við höldum sífellt áfram að nota marga hluti og fleygja peim í ruslið, pá eykst úrgangurinn stöðugt.

Bæði hjá okkur sjálfum en einnig par sem vörurnar eru framleiddar.

\section{HRÁEFNAPÖRF}

\begin{tabular}{ll}
\hline Stuttermabolur & $3 \mathrm{~kg}$ \\
\hline Gallabuxur & $7 \mathrm{~kg}$ \\
\hline Leðurskór & $31 \mathrm{~kg}$ \\
\hline Reiðhjól & $380 \mathrm{~kg}$ \\
\hline Fartölva & $442 \mathrm{~kg}$ \\
\hline DVD spilari & $1.714 \mathrm{~kg}$ \\
\hline Sambyggður kæliskápur og frystir & $2.159 \mathrm{~kg}$ \\
\hline Sjónvarp & ca. $2.500 \mathrm{~kg}$
\end{tabular}

\section{FRAMLEIĐSLA Á}

\section{EINU STYKKI}




\section{VERKEFNI 2}

\section{HVAĐ ERU ÚRGANGSFORVARNIR?}

\section{INNGANGUR}

prátt fyrir dugnað okkar við að safna og flokka úrgang verða engu að síður umhverfisáhrif. pess vegna er best ef við getum komið í veg fyrir að úrgangur myndist.

Um pessar mundir er rætt mikið um að koma í veg fyrir myndun úrgangs. Dæmi um petta er að kaupa notuð föt, sem er ein leið til pess að endurnýta fatnað.

\section{VERKEFNI}

Athugaðu hve miklu af fatnaði er fleygt heima hjá pér. Hverju fleygja foreldrar pínir? Hverju fleygir pú?

Pú getur gert pér í hugarlund hve miklu fólk um víða veröld fleygir í ruslið.

Á myndinni má sjá yfirlit yfir mannfjöldapróun á Jörðinni. Nú eru Jarðarbúar um 7 milljarðar, með öðrum orðum 7.000.000.000 manna búa á Jörðunni.

\section{Milljarðar manna}

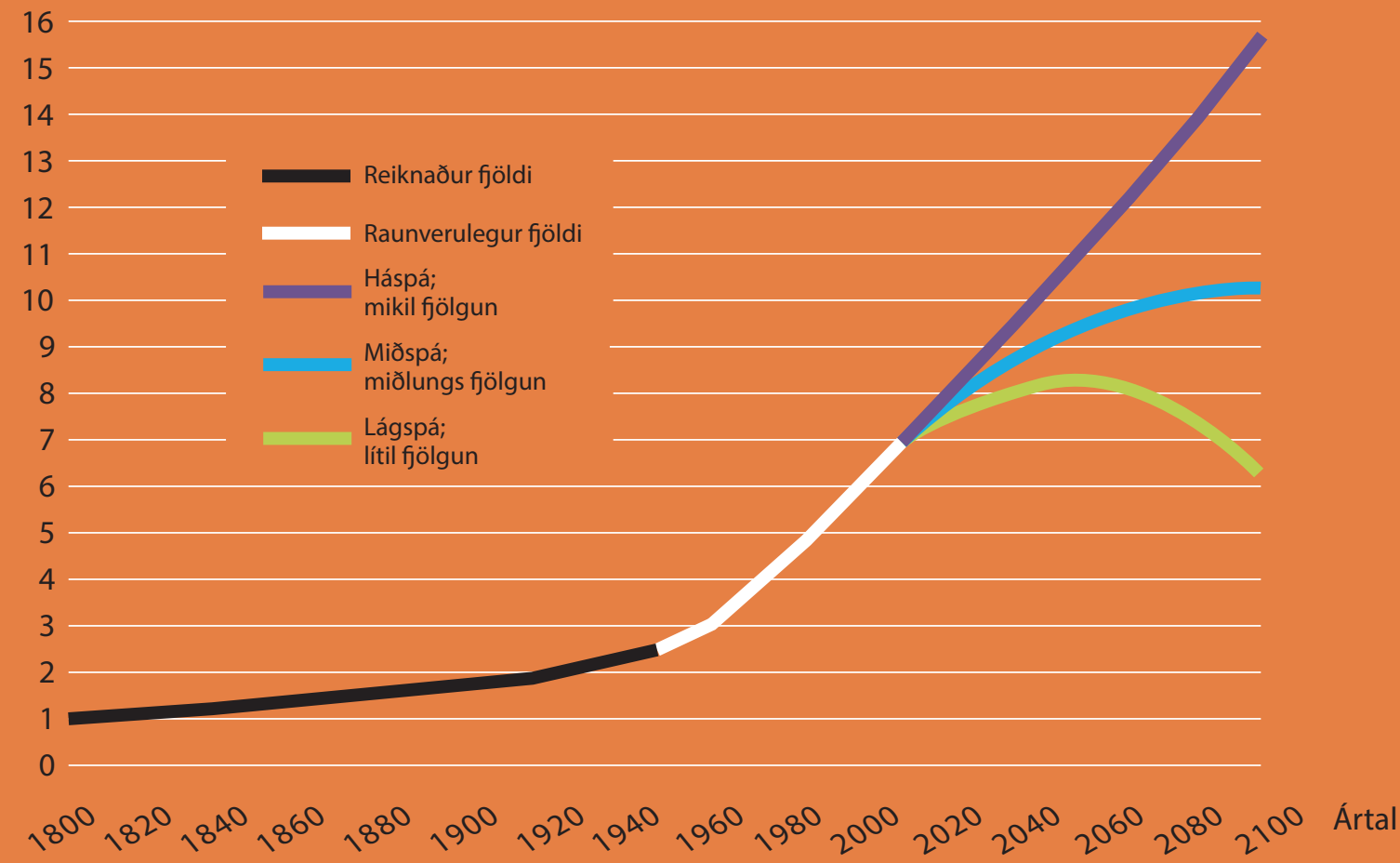


Hvað eru mörg ár frá pví að fjöldi fólks á Jörðinni var aðeins helmingur af pví sem nú er, eða aðeins 3,5

milljarðar?

Pað er áhugavert að íhuga ástandið í öðrum heimshutum pegar við hugsum um neyslu okkar og úrgang á Norðurlöndum.

Hvaða áhrif heldur pú að áhrif vaxandi fólksfjölgunar muni hafa á myndun úrgangs í veröldinni?

Allir hafa pörf fyrir mat, húsnæði, menntun og heilbrigðispjónustu.

Fólki finnst líka að pað hafi pörf fyrir eitt og annað ef pað hefur efni á pví.

Hugsið ykkur einhvern hlut sem fjöldi fólks í veröldinni vildi gjarnan eiga og bið sjálf eigið kannski nú pegar?
Teiknaðu mynd sem sýnir hvað verður um valinn hlut frá pví hann er framleiddur, par til farið er að nota hann. Hugleiddu:

$>$ Hvernig er hluturinn búinn til?

$>$ Hvaða aðföng og hráefni eru notuð við framleiðsluna?

> Hvaða hráefni eru sótt til annarra landa?

$>$ Hvar myndast úrgangur?

Athugaðu hvernig hægt er að fyrirbyggja myndun úrgangs í tengslum við hlutinn sem pú teiknaðir mynd af.

pið getið á næstu síðu skoðað myndræna framsetningu á framleiðsluferli farsíma.

Í framtíðinni mun fólki á Jörðinni fjölga enn meira.

Hvað finnst pér um pað háttarlag manna að halda áfram að nota og fleygja, bæði á Norðurlöndum og annars staðar í veröldinni?

\section{VŐRUR SKILJA EFTIR SIG SPOR}

Einstakar vörur skilja eftir sig spor á margan hátt.

Vistspor okkar er til marks um hve mikið af Jarðargæðum við nýtum við neyslu okkar og hve mikill úrgangur og mengun verður af okkar völdum.

Pegar borað er eftir olíu á landi, til dæmis í Perú, eru rudd stór landflæmi vaxin regnskógi og jarðvegurinn er mengað̌ur með̃ miklu magni eiturefna.

Pegar plast er framleitt nota vélarnar eldsneyti. Brennsla eldsneytis mengar loftið með $\mathrm{CO}_{2}$.

Pegar auðlindir; hráefni og fullunnin vara er flutt til landsins parf auk pess eldsneyti. 


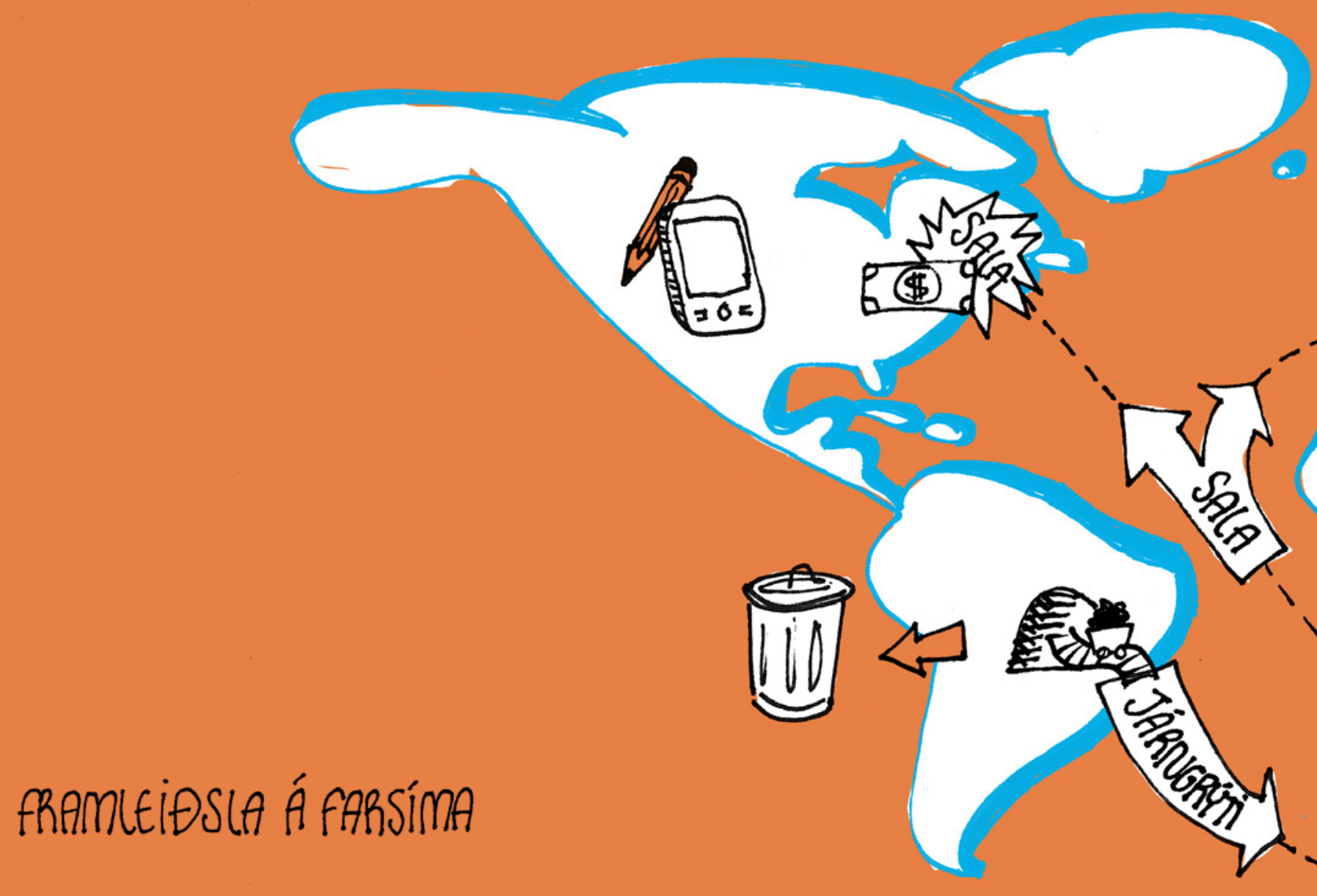

\section{VEIST PÚ?}

$\mathrm{CO}_{2}$ er gróðurhúsalofttegund. Pess vegna á $\mathrm{CO}_{2}$ pátt í hlýnun Jarðarinnar.

Tré „borða“ gróðurhúsalofttegundir og koma pví að gagni við að stöðva hlýnunina. 


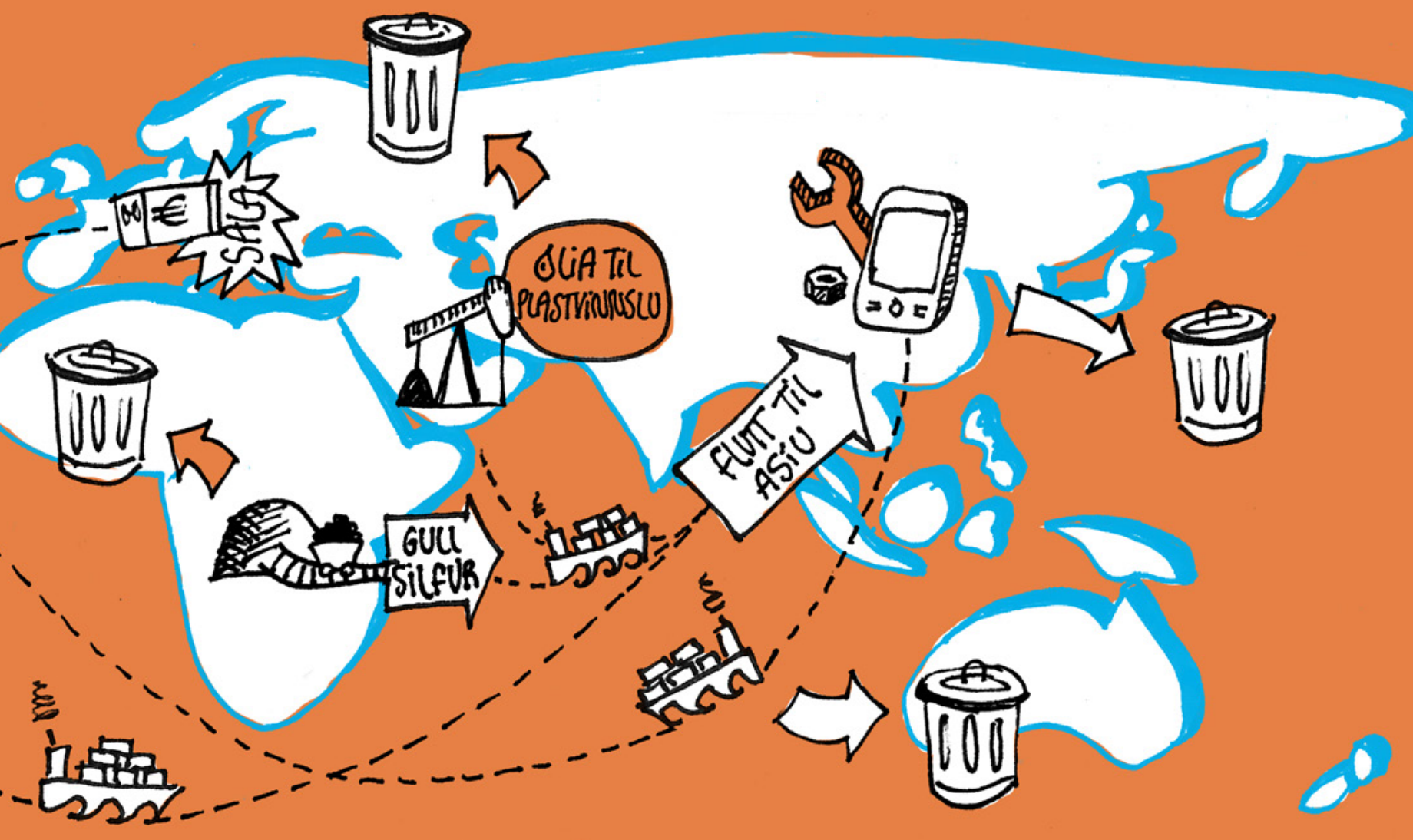

\section{VEIST PÚ?}

$>$ Í einn farsíma parf 75 kg af hráefni og mikill úrgangur myndast áður en síminn er tilbúinn til notkunar.

> Pau efni sem notuð eru í farsíma eru pessi: plast 56\%,25\% málmar og 16\% keramik. Afgangurinn 3\% eru ýmis eiturefni og lítilsháttar af gleri.

$>$ Plast er unnið úr olíu.

$>$ Keramik er unnið úr leir.

$>$ Gler er framleitt úr sandi.

> Málmar eru úr námum um víoa veröld. 


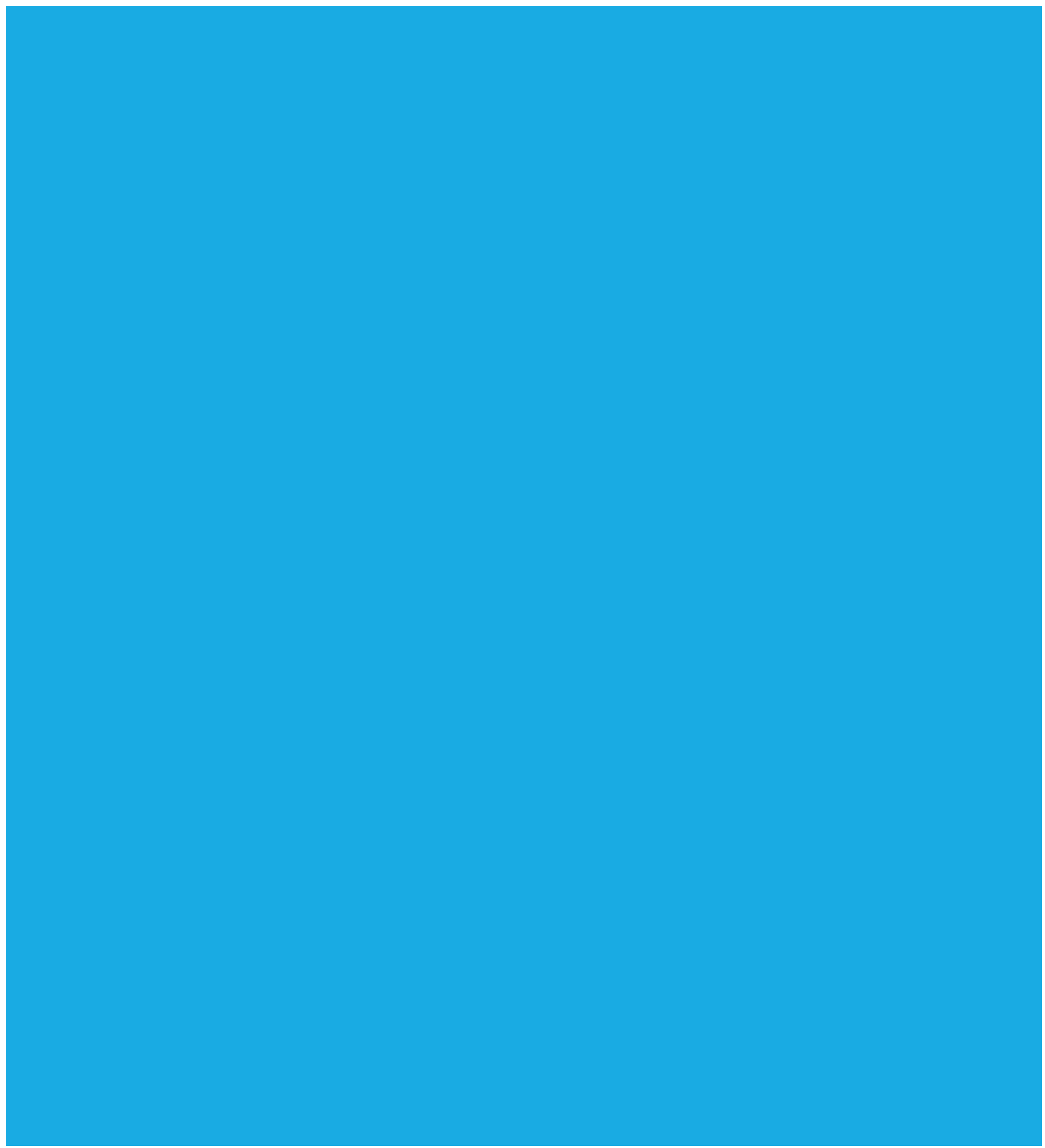




\section{FATIUADUR}

VERKEFNI 3

VERKEFNI 4

VERKEFNI 5 


\section{VERKEFNI 3}

\section{HVERNIG ER STUTTERMABOLUR FRAMLEIDDUR?}

INNGANGUR

Pegar pú kaupir stuttermabol hefur hann farið um langan veg og við gerð hans hafa verið notuð mörg hráefni. Vera má að bómullin í bolnum sé ræktuð í Afríku, práour spunninn í Póllandi, efnið ofið í Rússlandi, litað á Indlandi, saumað í Kína og bolnum innpakkað í Osló áour en hann er sendur til sölu í versluninni. Reyndar getur stuttermabolur farið nokkrum sinnum umhverfis hnöttinn, allt frá bómullarakri par til hann er tilbúinn til sölu í fjarlægu landi.

\section{VERKEFNI}

Hvar er stuttermabolurinn pinn framleiddur og úr hvaða efni er hann gerður?

Teiknaðu mynd af ferðalagi stuttermabolsins píns og segðuu bekkjarfélögum pínum frá hugsanlegum við̌komustöðum.
Gerðu lista yfir pau efni sem bolurinn pinn er gerður úr (hafð̃u einnig í huga efni sem ekki eru skráo á upplýsingamiðann, - pað getur verið litarefnið sem notað̆ var til að̆ lita stuttermabolinn pinn eða áprentuð̃ mynd).

Hvar á liftíma stuttermabolsins heldur pú að̃ mest orka sé notuð? Er pað̌ við uppskeru á bómullinni, pegar bolurinn er saumaður eða litaður, eða er pað í öll skiptin sem bolurinn er pveginn og ef til vill purrkaður í purrkara?

Hvað verður venjulega um stuttermabolinn pinn pegar pú vilt ekki lengur nota hann?

Kemur eitthvað annað til greina?

Getur pú með fatanotkun pinni orðið pátttakandi í að̃ minnka úrgang?

\section{VEIST PÚ?}

Föt og vefnaðarvara er framleidd bæði úr náttúrulegu efni og gerviefni.

Náttúrulegar trefjar eru unnar úr plöntum (bómull, hampur, bambus, soja), trjám og einnig dýraafurðum (sauðfé, silkiormar, lamadýr).

Gervitrefjar eru unnir úr olíu, s.s. polyester, akrýl, lycra ofl.

\section{VEIST PÚ?}

Til pess að framleiða $1 \mathrm{~kg}$ af bómull parf allt að 29.000 lítra af vatni. Við framleiðslu á einu kílói af bómull losna 15 kg af gróðurhúsalofttegundum. 


\section{FRAMLEIESLA Á BÓMUCARFATNAAPI}

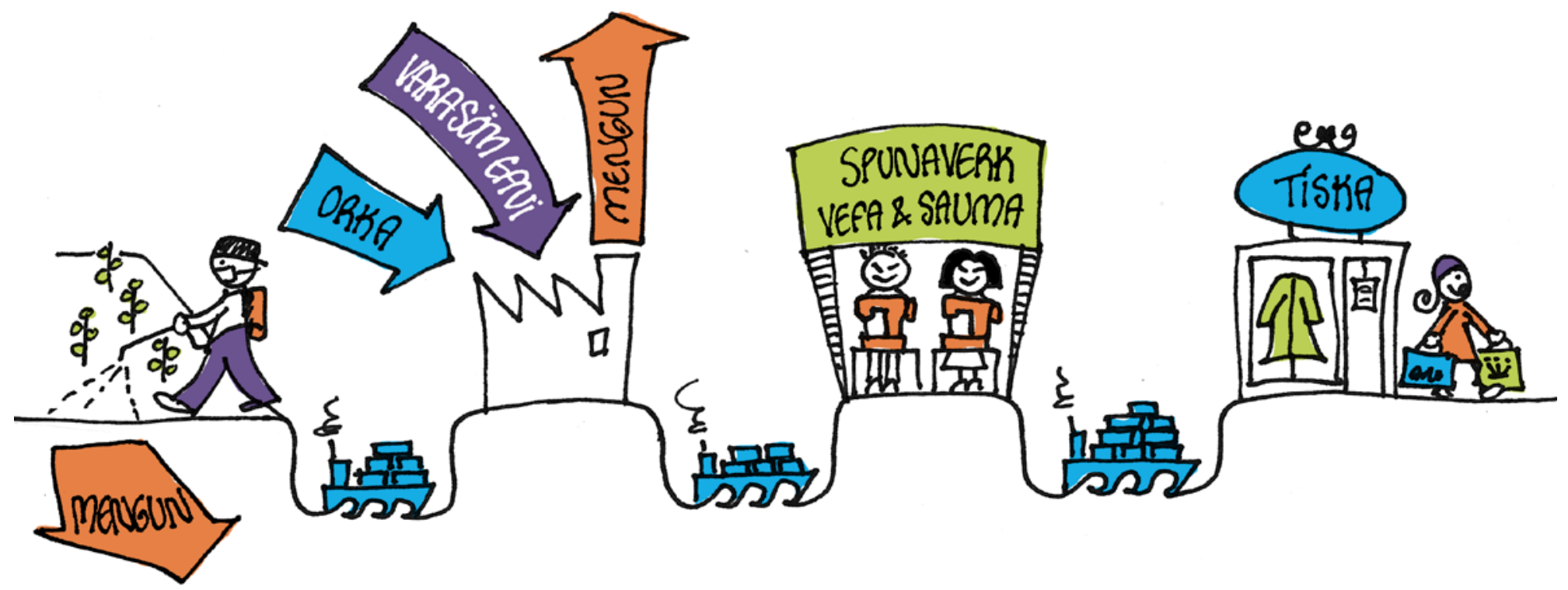

\section{HEFUR PÚ HUGLEITT?}

> Föt er hægt að nota lengur ef pau eru gefin vinum eða ef fatnað̌i er komið í fatasöfnunargáma pegar eigandinn er hættur að nota fötin sín.

$>$ Fötin pín endast einnig lengur ef pau eru einungis pvegin pegar pau eru orðin óhrein, ekki bara ef pú hefur verið í peim hálfan dag og ætlar að skipta um föt.

> Pegar pú ætlar að̃ kaupa ný föt athugaðu hvort pau eru merkt með umhverfismerki s.s. Blóminu eða Svaninum. Ef svo er, pá stuðlar pú að pví að minnka notkun eitraðra efna.

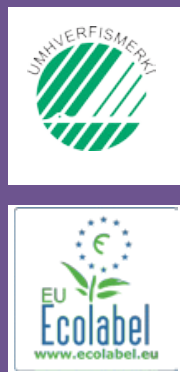




\section{FRAMLEIDSLA Á AATUAADI ÚR GERVIEFAUUM}

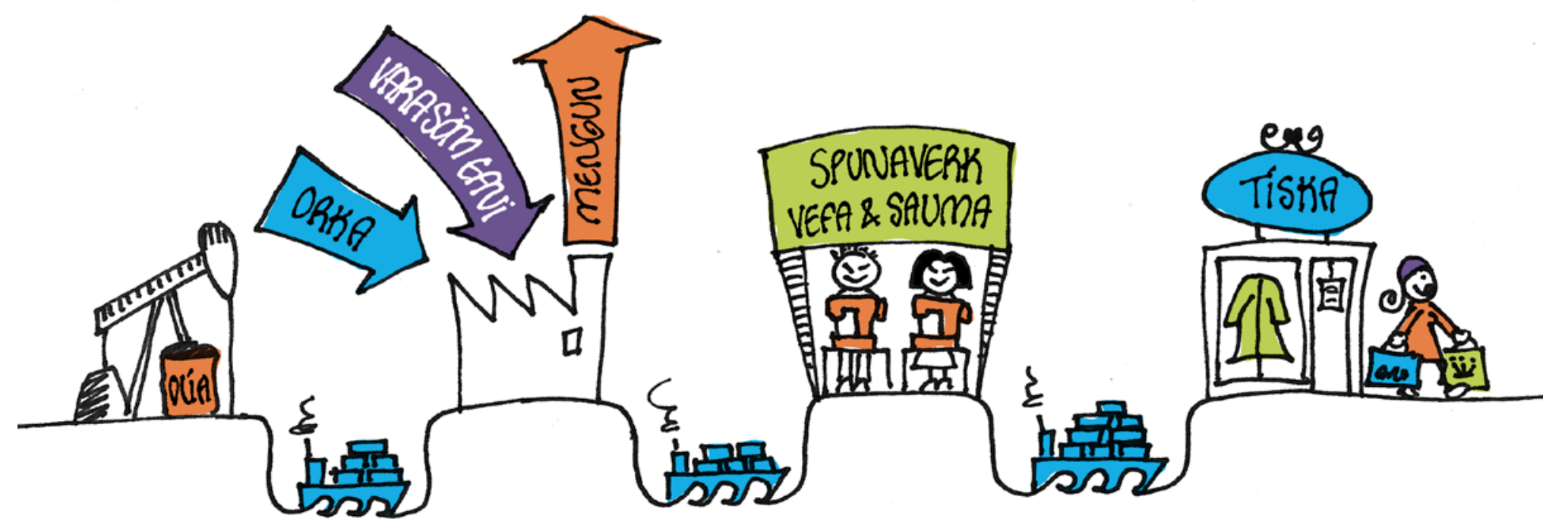

\section{VEIST PÚ?}

> Præð̌r úr gerviefni, s.k. syntetísk trefjaefni eru framleiddir úr hráolíu og jarðgasi við vinnsluferli sem er afar orkufrekt.

> Til að framleiða práð úr gerviefni er plasti prýst í gegnum mót og úr pví kemur práðurinn.

$>$ Við framleiðslu á trefjaefni úr olíu eru notuð efni- og efnasambönd sem geta verið hættuleg umhverfi og heilsu.

> Í fatnað og vefnaðarvöru er ýmist notuð blanda gerviefna eða blanda náttúrulegra efna og gerviefna.

$>$ Algeng hlutföll pessara efna í fatnað̌i er 65 prósent bómull og 35 prósent polyester. Lesið á merkimiðana sem eru saumað̌ir á fötin ykkar. 


\section{VERKEFNI 4}

\section{HVERNIG LENGJUM VIĐ LÍFTÍMA FATNAĐAR?}

\section{INNGANGUR}

Kannski átt pú föt heima hjá pér sem pú notar ekki lengur eða hefur fengið leiða á. Í stað pess að fleygja fötunum getið pið̌ safnað̃ saman notuð̌u fötunum og komið með hugmyndir um hvað̌ hægt er að̃ gera til að̆ lengja líftíma peirra. Ef til vill getið pið fengið áhugaverð föt án pess að pað kosti mikið fé, fyrirhöfn eð̃a hráefni.

Skoðið myndirnar á blaðsíðum 18 og 20. Kannski fáið pið̌ hugmyndir um hvað hægt er að̃ gera.

\section{VEIST PÚ?}

$>$ Við bómullarrækt er ógrynni eiturefna úðað yfir plönturnar og mikið magn af tilbúnum áburði er borið á jarðveginn.

$>$ Við bómullarrækt parf mikið vatn til vökvunar.

> Bómull sem úðuð hefur verið með eiturefnum er hættuleg fólki sem annast bómullartínslu ef pað notar ekki öndunargrímu og hanska sér til hlífðar.

\section{VERKEFNI}

Ræðið̌ við bekkjarfélagana um hvernig pið getið gefið gömlum fötum nýtt líf.

Hvað getið pið gert við notuð föt af ykkur sjálfum?

Hver verða áhrifin á umhverfið við meiri endurnýtingu á fötum?

Hvaða kostir og gallar fylgja pví fyrir ykkur að endurnýta föt?

Komið með nokkrar hugmyndir um hvað væri heppilegt að gera við notuð föt?

Skrifið á blað prjár bestu hugmyndir ykkar.

Að pví loknu getið pið bekkjarfélagarnir kastað fram hugmyndum ykkar og rætt pær. 


\section{NOTKOON QG ENOURNUÝTing}

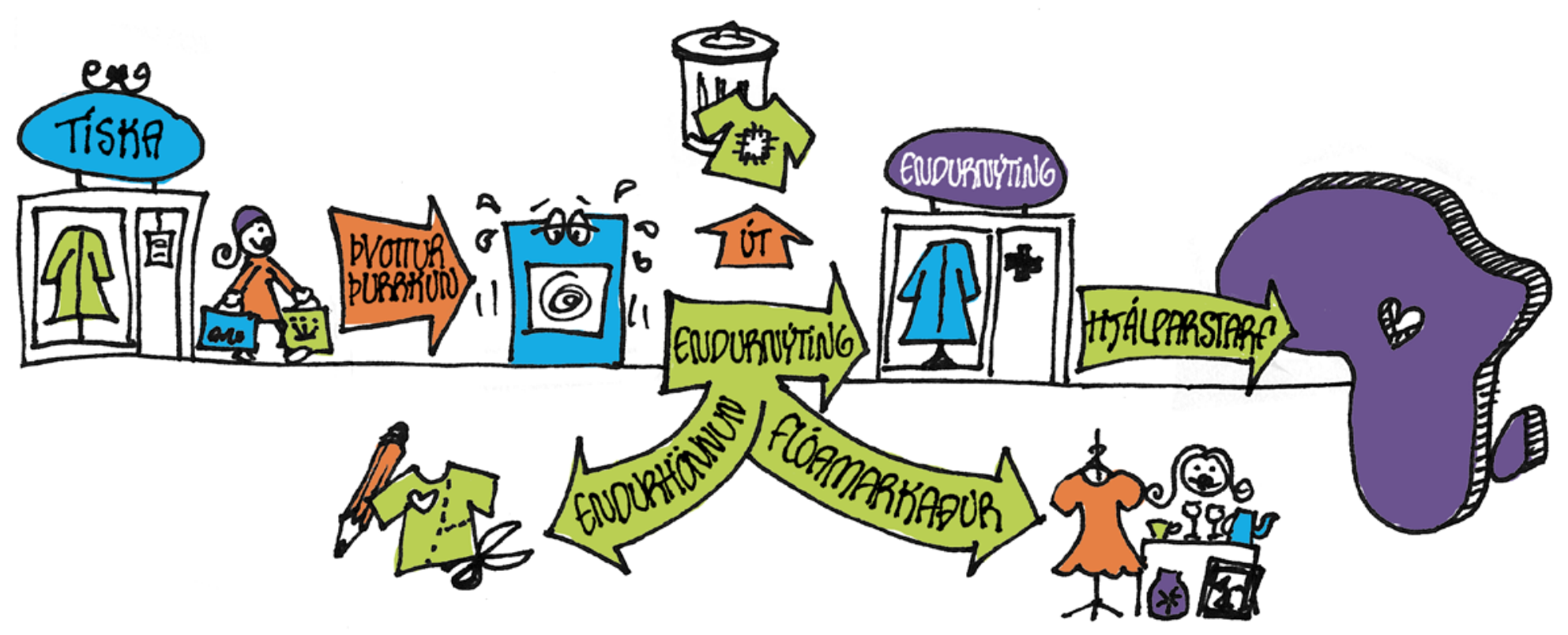

\section{VEIST PÚ?}

> Fyrir hverja eina flík sem er endurnotuð parf aðeins 2-3 prósent af pví hráefni sem annars hefði farið í að framleiða nýja flík.

> Til að framleiða einn stuttermabol sem vegur 300 grömm parf að nota hráefni sem vegur 3,5 kíló og 2,700 lítra af vatni.

\section{VEIST PÚ?}

Mesta orkunotkunin á lífsferli stuttermabols verður pegar hann er pveginn og purrkaður áður en hann fer til sölu í verslun.

\section{HEFUR PÚ HUGLEITT?}

$>$ Að kaupa notuð föt dregur úr úrgangi og auð̌lindir og hráefni sparast.

$>$ Í stað pess að fleygja fötum í ruslið getur pú gefið pau til hjálparstarfs, til endurvinnslu eða selt pau á flóamarkaði. 


\section{VERKEFN 5}

\section{FINNIĐ YKKUR VIĐFANGSEFN I}

\section{INNGANGUR}

Ef til vill hefur pú eða foreldrar pínir fleygt ógrynni af fötum sem passa ekki eða pið viljið ekki nota lengur. Hefur pú hugleitt að fötin má endurnota og endurvinna öðrum til gleð̃i.

\section{VERKEFNI}

Pú og nokkrir bekkjarfélagar pínir ættuð í hópvinnu að̆ koma ykkur saman um að̆ vinna að viðburði eða verkefni sem hefur pað að markmiði að lengja líftíma á fatnað̃i, til pess að̆ aðrir geti haft ánægju af pví sem annars færi í ruslið.

Hvernig getið pið endurnýtt fatnað sem annars færi í ruslið?

pið gætuð kannski fundið aðferð til að lána föt eða skipta á fötum?

Ef til vill getið pið saumað ný og falleg föt upp úr gömlum eða selt notuð föt á flóamarkað̌i?

Pegar pið hafið ákveðið hvað pið viljið gera purfið pið̌ að ákveða hvernig pið ætlið að hrinda verkinu í framkvæmd.
> Hvar ætlið pið að vinna verkið?

$>$ Hverjir eru pátttakendur?

> Hvernig á að̃ vinna verkið?

> Hvaða efni og áhöld parf hugsanlega til verksins?

pegar pið hafið ákveðið hvað pið getið hugsað ykkur að gera, getið pið valið einn úr hópnum til að kynna ykkar hugmynd fyrir hinum í bekknum. Síðan skulið pið ákveða:

$>$ Hve langur tími er til ráōstöfunar (frá upphafi til enda)?

$>$ Hver er ábyrgur fyrir hverju?

> Hvernig pið getið hjálpað hvert öðru?

Munið að skrifa allt niður eð̃a teikna til pess að pið gleymið ekki hvað pið hafið ákveðið.

Pegar verkefninu er lokið getið pið sagt hinum í bekknum frá pví hvernig ykkur gekk. pið getið sagt frá pví sem gekk vel og pví sem miður fór. pið getið líka talað um hvort pið mynduð̃ gera eitthvað öđruvísi í næsta skipti. Auk pess getið pið sagt frá pví hvað pið hafið lært af verkefninu. 


\section{FATALÁNASAFN}

„Ég hef frétt af kröftugum og klárum bekkjarfélögum í skóla í pýskalandi sem hafa verið hugmyndarík og hrint í framkvæmd sínu eigin verkefni. Sumum nemendum fannst rosalega pirrandi pegar foreldrar peirra vildu ekki kaupa handa peim ný föt pegar peir vildu, eða ef einhver í bekknum hafði fengið flott föt og pau vildu fá eins.

Svo fundu pau upp á pví að lána hvert öðru föt.

Í ljós kom að í skólanum voru margir sem gjarnan vildu taka pátt í,fatalána verkefninu“, svo að pau komu sér upp inn og útlánakerfi rétt eins og á bókasafni, en bara fyrir fatnað. Eftir petta purftu pau ekki sínkt og heilagt að suða í foreldrum sínum um að fá ný föt, pau fóru bara á „fatalánasafnið” og fengu

lánuð föt par. Var petta ekki snjallt hjá peim? Ég gæti best trúað að pau hafi útbúið „fatalánakort" til að halda utan um hver fékk hvaða flík að láni
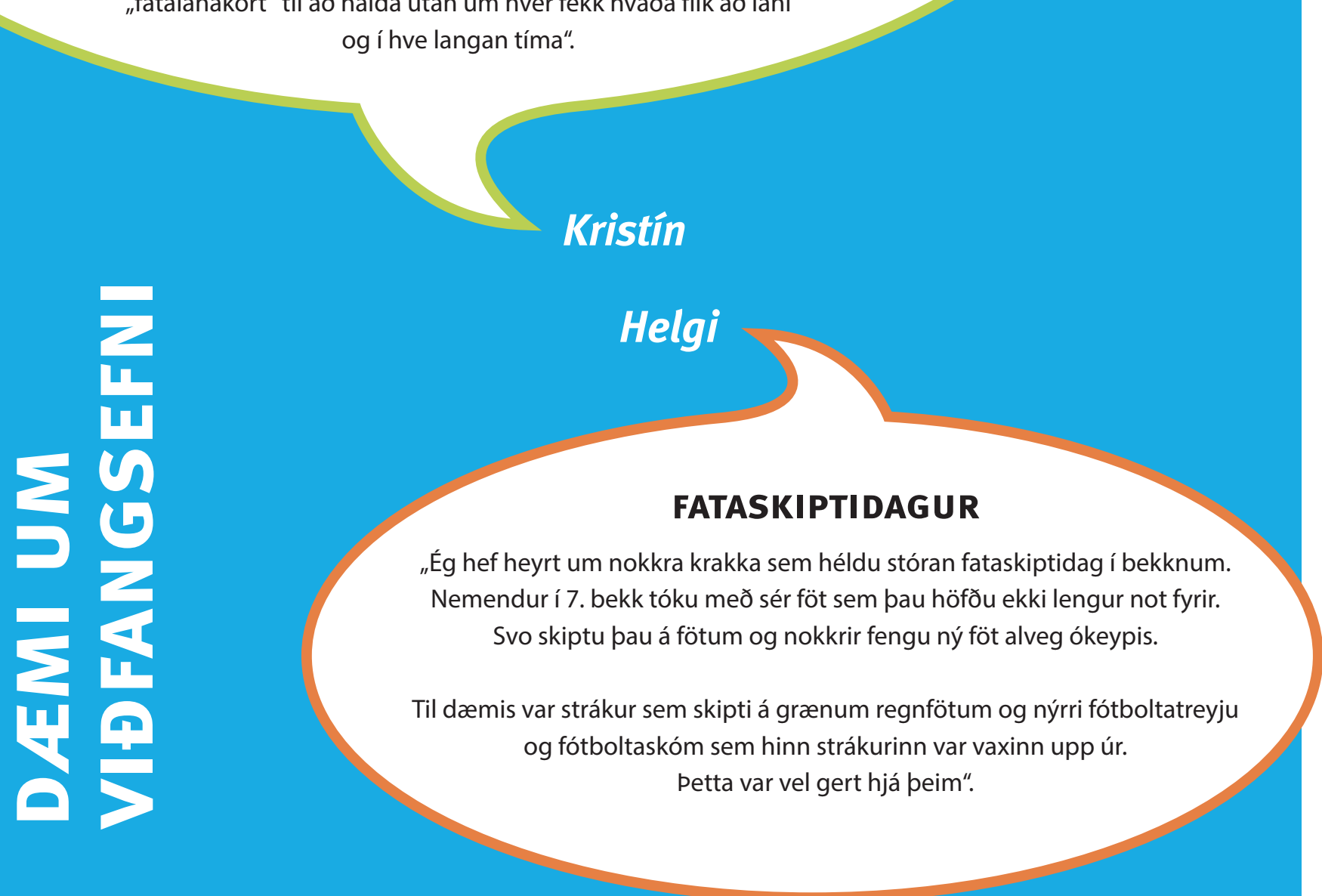


\section{FATAGJAFIR TIL VINA EĐA \\ GÓĐGERĐARSAMTAKA}

„Við getum pá bara gefið vinum eða einhverjum í fjölskyldunni pau föt sem við viljum ekki nota í stað pess að henda peim bara í ruslatunnuna. pá er einhver sem nýtur góðs af og líftími fatanna lengist.

Ef enginn vill eiga fötin er líka hægt að gefa pau til góðgerðarsamtaka, mamma sagði mér frá pví. Við fylltum einu sinni nokkra poka af fötum heima og settum pá í söfnunargám Rauða krossins.

\section{AĐ HALDA FLÓAMARKAĐ MEĐ FÖT}

„Ég hef aðra frábæra hugmynd. Við getum pénað peninga í stað pess að fleygja fötunum, með pví að halda fataflóamarkað.

Við gætum sett upp nokkra sölubása annaðhvort í skólanum eða annars staðar, eða við gætum selt föt á netinu.

Ég veit um nokkra staði par sem fólk hengir upp myndir af fötum

sem pað vill selja. Mjög margir sjá pessar myndir,

ekki bara peir sem búa í bænum okkar".

\section{Vitið pið hvað verður um fötin sem við setjum í söfnunargámana?"}




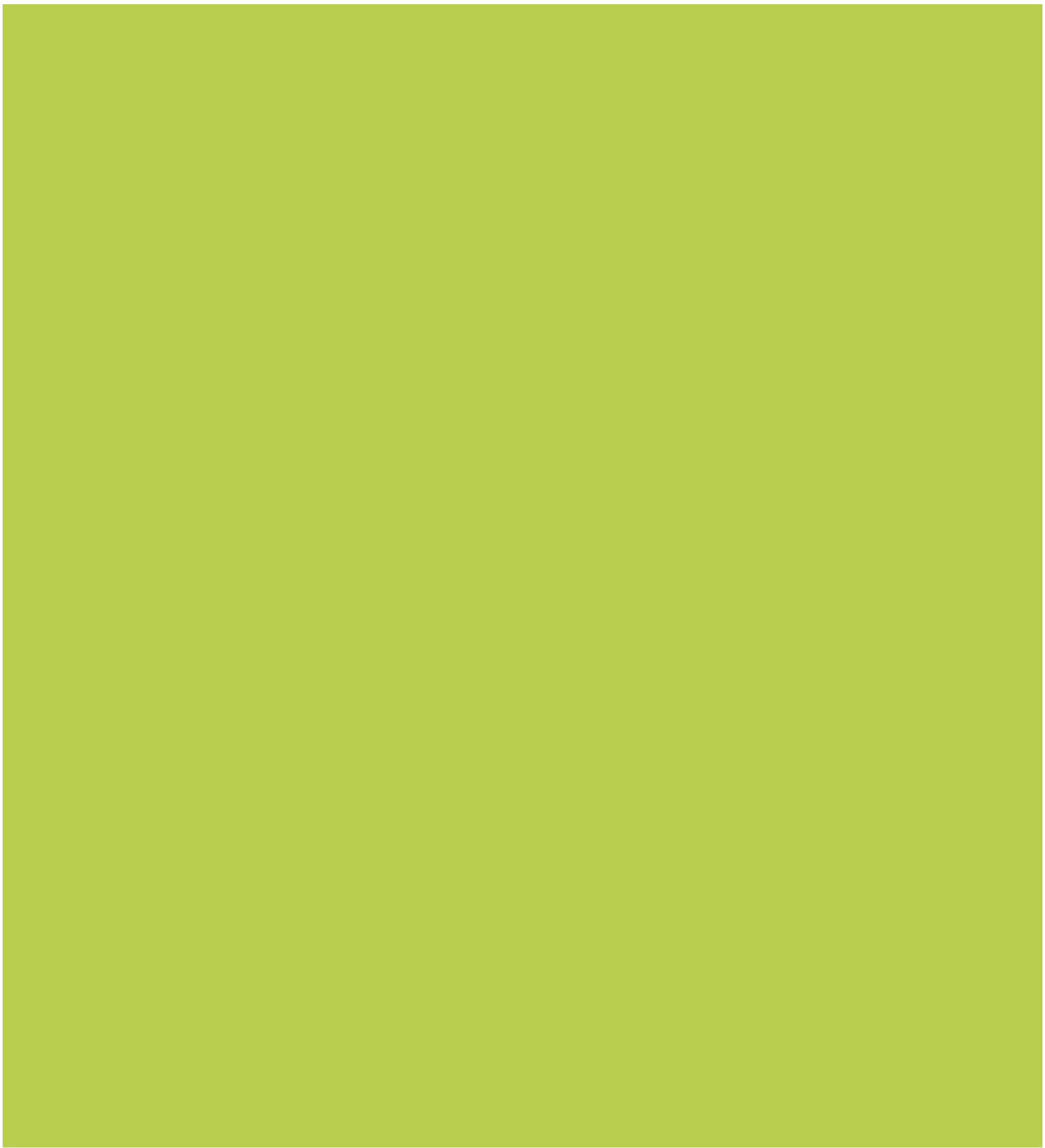




\section{MATUR}

VERKEFNI 6

VERKEFNI 7 


\section{VERKEFNI 6}

\section{HVENAER FLEYGJUM VIĐ MAT?}

\section{INNGANGUR}

Pú hefur sjálfsagt einhverntíman tekið meiri mat á diskinn en pú getur borðað. Pú hefur kannski líka komist að raun um að mjólkin í kæliskápnum er orðin of gömul. En hefur pú hugleitt hvað pað kostar að kaupa pann mat sem endar í ruslinu?

\section{VERKEFNI}

Vigtið allan mat sem fer til spillis á heimilinu á einni viku og notið eyðublaðið á bls. 31 til pess að reikna verð og pá $\mathrm{CO}_{2}$ losun sem hlýst af matarsóun fölskyldunnar. Að viku liðinni geta nemendur borið saman niðurstöðurnar.

Reiknið út að viku liðinni hve miklir peningar hafa farið í súginn á heimilinu vegna matarsóunar.
Reiknið út eftir eina viku hve mikla $\mathrm{CO}_{2}$ losun hefði mátt koma í veg fyrir með pví að borða matinn í stað pess að fleygja honum.

Komist að pví í sameiningu hvaða mat er fleygt mest af.

\section{Hvernig er matarsóun háttað í pínu heimili?}

Hvernig getum við komist hjá matarsóun?

Hverju öðru en sjálfum matnum fleygjum við?

Hvers er að vænta í framtíðinni? Verður meiri eða minni matarsóun á Norðurlöndum í framtíðinni?

\section{VEIST PÚ?}

$>$ Mikið vatn er notað við matvælaframleiðslu.

$>$ Til pess að framleiða $1 \mathrm{~kg}$ af nautakjöti parf 15,000 lítra af vatni.

> раð parf u.p.b. 175 lítra af vatni til að laga kaffi í einn kaffibolla.

\section{HEFUR PÚ HUGLEITT?}

Við getum oftast pefað, smakkað eða preifað á til að ganga úr skugga um hvort matur er neysluhæfur. 


\section{DAEMI UM MATARSÓUN}

$>$ Að taka meira á diskinn sinn en maður er viss um að geta borðað.

> Að fleygja matarafgöngum í stað pess að̃ geyma pá í kæliskáp eða frysti.

> Að kaupa svo mikinn mat að ekki er hægt að borða hann í tíma.

> Að fleygja mat löngu áđur en dagstimplun segir til um.

> Að gleyma að̆ nota allan matinn í kæliskápnum áđur en við kaupum nýjan mat.

> Aðð fleygja endabrauð̃sneið̌um í ruslið.

> Að fleygja ystu salatblöðunum pó að ekkert sé að̃ peim.

> Að hella niður afgangi af mjólk eða ávaxtasafa pó ekkert sé að drykknum.

$>$ Að fleygja skorpnum eplum.

$>$ Að̆ fleygja endanum á agúrkunni.

$>$ Að afhýða nýjar kartöflur.

$>$ Að̆ opna of margar matarumbúơir í einu.

> Að gleyma að̃ skipuleggja matseld fram í tímann.

> Að̆ gleyma að̆ nota matarafganga, til dæmis í nesti.

> Að kaupa of mikið í hvert skipti.

> Að gleyma að borða upp úr frystinum áður en við setjum par nýjan mat.

> Að útbúa svo stóra matarskammta við við getum ekki klárað̆ matinn.

> Að gleyma að frysta mat í hæfilega stórum neysluskömmtum.

$>$ Aðð nota ekki græna toppa af mörgum grænmetistegundum, eða t.d. spergilkálkjarna sem annars væri hægt að nota í súpur, pesto eða í salat.

Stop spild af mad, 2018

www.stopspildafmad.dk/madspild

\section{VEIST PÚ?}

> Framleiðsla á nautakjöti hefir 20-50 sinnum meiri áhrif á loftslagið en ræktun á kartöflum, gulrótum, maís og hafragrjónum.

$>30-40 \%$ af öllum mat sem framleiddur er í veröldinni endar ekki í maga okkar, heldur fer til spillis.

$>$ Áætla má að hjón með tvö börn fleygi mat fyrir að meðaltali um 240,000 krónur árlega. Рað er um 25\% af heildarmatarútgjöldum fjölskyldunnar á ári.

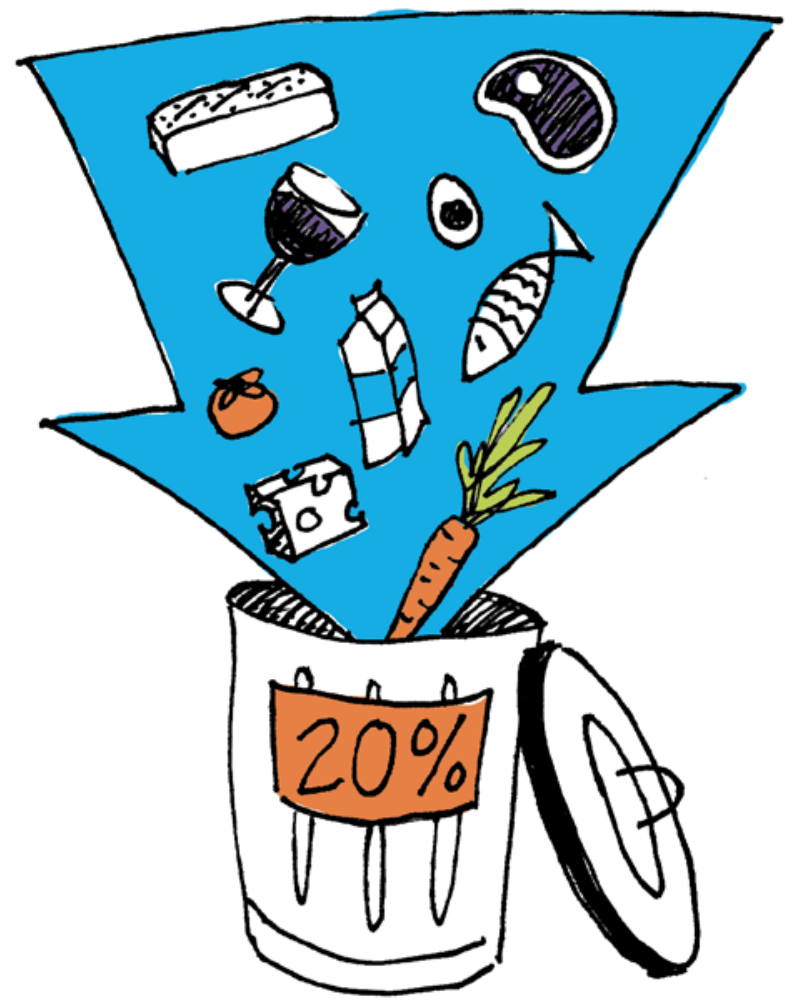




\section{VERKEFNI 7}

\section{HVE MIKLUM MAT ER FLEYGT Í MATVÖRUVERSLUNUM?}

\section{INNGANGUR}

Hefur pú hugleitt hve mikill matur fer til spillis daglega vegna pess að hann hefur ekki selst í matvöruversluninni? Kannski hefur pú valið fallegustu ávextina í matvörubúðinni eða pú hefur séð foreldra pína velja kjöt í pakkningu sem hefur ástimplaðan sem lengstan endingartíma, jafnvel pó að kjötið eigi að elda og borða samdægurs. pú ásamt bekkjarfélögum pínum getur kannað hve miklu og af hverju mat er fleygt í matvöruverslunum. Er ávöxturinn með brúna bletti, er komið fram yfir síðasta leyfilegan söludag eða er einhver önnur ástæða fyrir pví að maturinn selst ekki?

\section{VERKEFNI}

Farið í heimsókn í matvöruverslun og ræðið við starfsfólkið um matarsóun.

\section{ÁĐUR EN pið farið í heimsókn í matvöruverslun}

Skrifið upp lista í hópavinnu yfir pær matartegundir sem pið haldið að fari mest til spillis í matvöruverslunum og hvaða matvæli fara par síður til spillis.

Hvernig vitum við sem viðskiptavinir í matvöruverslun að einhver matvara er hvorki söluhæf né neysluhæf?

Er pað gott eða slæmt?

Útbúið nokkrar spurningar sem gott væri að fá svör við pegar pið farið í heimsókn í matvöruverslunina.
Spurningarnar geta verið á pessa leið:

Hvernig getur matvöruverlsun staðið sig betur í að selja matvöru sem er að nálgast síðasta söludag, svo ekki purfi að fleygja matnum í ruslið?

Getur verslunin leyst vandann í samvinnu við viðskiptavini? (Ef á ykkur brenna spurningar um eitthvað annað en matarsóun, pá skuluð pið einnig skrá pær á spurningalistann).

Undirbúið einnig spurningar um pað sem pið sjálf viljið spyrja sérstaklega um.

Ákveðið hverjir í hópnum eiga að spyrja og hver og hvernig eigi að skrá svör við spurningunum.

\section{MEĐAN á heimsókn stendur}

Minnið hvert annað á hvað pið hafið ákveðið að gera og hver á að gera hvað.

Skrifið hjá ykkur ný atriði sem ekki hafa verið undirbúin ef pau eru viðeigandi.

Íhugið einnig hvort nokkuð kemur fram sem pið viljið koma á framfæri heima hjá ykkur.

Hafið pið nokkrar hugmyndir fram að færa um hvernig hægt er að minnka matarsóun í matvörubúðum? 


\section{AĐ heimsókn lokinni}

Farið yfir svörin við spurningum ykkar. Hvers hafið pið orðið vísari?

Ræðið í bekknum hve stórt vandamál pað er ef mat er fleygt í matvöruverslunum.

Hvernig haldið pið að ástandið sé í öðrum verslunum sem selja mat?

Hafið til einhverjar tillögur um hvort pið getið gert eitthvað sem yrði til pess að minna af mat yrði fleygt?

Sumar verslanir selja einungis mat í dósum, flöskum eða purrmat svo sem mjöl í pokum.

> Hvaða kostir eru við slíkar verslanir?

$>$ Hvaða ókostir eru pað fyrir verslunina?

$>$ Hver er ávinningurinn fyrir neytendur?

$>$ Hvaða ókostir geta pað verið fyrir neytendur?

pegar pið hafið komist að pví hvaða matur pað er sem endar í ruslatunnunni í matvöruversluninni, getið pið rætt um hvað hægt er að gera til pess að koma í veg fyrir að svo miklum mat sé fleygt í ruslið. pó að fólk geti ekki lagt matinn sér til munns mætti ef til vill fóðra einhver dýr á matnum? Hvernig getum við fengið fólk til pess að kaupa matvörur sem nálgast "notist fyrir" dagsetningu?

Til pess að allir geti skilið tillögur ykkar um hvernig minnka má matarsóun í matvöruverslunum gæti pað verið góð hugmynd að gera veggspjald eða klippimynd til að útskýra tillögur ykkar.

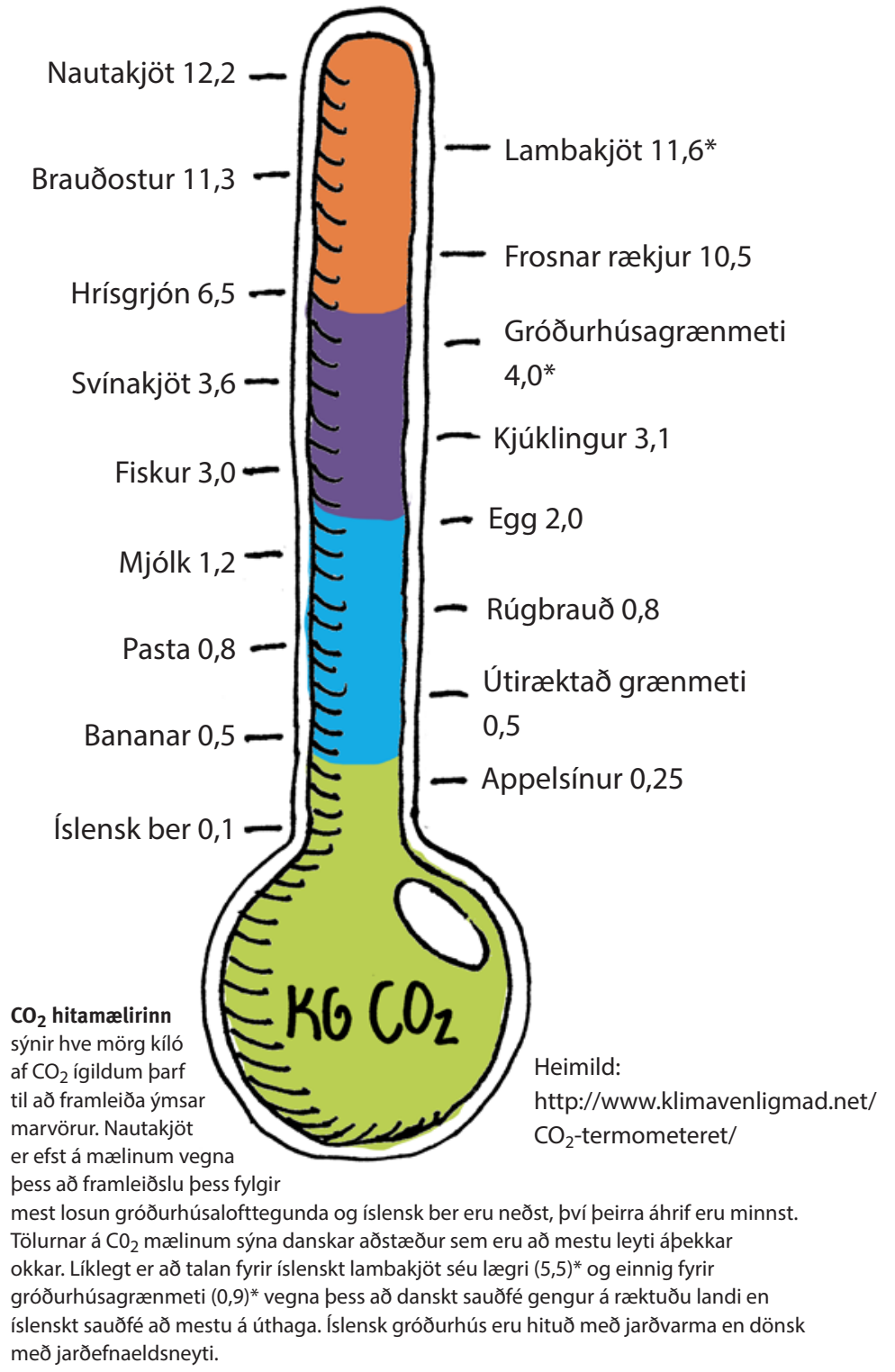

\section{HEFUR PÚ HUGLEITT?}

Við borðum ávexti, grænmeti og fisk og kjöt af bæði spendýrum og alifuglum. pað er mikill munur á pví hve mikill úrgangur kemur frá framleiðslu pessara afurða. 


\begin{tabular}{lr} 
Nautahakk & $1,540 \mathrm{kr}$. \\
\hline Lambakótilettur & $2,310 \mathrm{kr}$. \\
\hline Brauðostur & $1,470 \mathrm{kr}$. \\
\hline Frosnar rækjur & $1,470 \mathrm{kr}$. \\
\hline Hrísgrjón & $430 \mathrm{kr}$.
\end{tabular}

Gróðurhúsagrænmeti:

$\begin{array}{ll}>\text { Tómatar } & 390 \mathrm{kr} . \\ >\text { Agúrkur } & 440 \mathrm{kr} . \\ >\text { Paprika } & 435 \mathrm{kr} .\end{array}$

\begin{tabular}{lr} 
Svínakótilettur & $1,400 \mathrm{kr}$. \\
\hline Kjúklingabringur & $2,250 \mathrm{kr}$. \\
\hline Lax & $1,915 \mathrm{kr}$. \\
\hline Egg & $695 \mathrm{kr}$. \\
\hline Mjólk & $128 \mathrm{kr}$. \\
\hline Rúgbrauð & $880 \mathrm{kr}$. \\
\hline Pasta & $205 \mathrm{kr}$.
\end{tabular}

Útiræktað grænmeti

\begin{tabular}{ll}
\hline$>$ Gulrætur & $385 \mathrm{kr}$. \\
\hline$>$ Blómkál & $340 \mathrm{kr}$. \\
\hline$>$ Hvítkál & $190 \mathrm{kr}$. \\
$>$ Kartöflur & $245 \mathrm{kr}$.
\end{tabular}

\section{VEIST PÚ?}

Stórmarkað̌ir og matvöruverslanir fleygja stundum heilum pakka af tómötum enda pótt aðeins einn tómatur sé skemmdur. Stundum er matvöru hent í ruslið ef umbúðir eru skaddaðar pó maturinn sé ílagi.

\section{HEFUR PÚ HUGLEITT?}

Ein ástæða matarsóunar í stórmörkuðum og matvörubúðum er kauphegðun okkar sjálfra. Við veljum fallegustu ávextina og matvöru með sem lengstan geymslutíma. 


\section{EYĐUBLAĐ TIL AĐ SKRÁ MATARSÓUN}

Hér getur pú skráð hvaða matvöru er fleygt, af hverju matnum er fleygt og hve mörgum kílóum er fleygt. Með pví að styðjast við upplýsingar um einingaverð, pyngd og $\mathrm{CO}_{2}$ ígildi getur pú reiknað út verðmæti matarins sem fer til spillis og hve mikil $\mathrm{CO}_{2}$ losun hlýst af matarsóuninni.

Matvara Ástæða pess að mat er fleygt

Pyngd kg. Verð kr. $\mathrm{CO}_{2}$ 


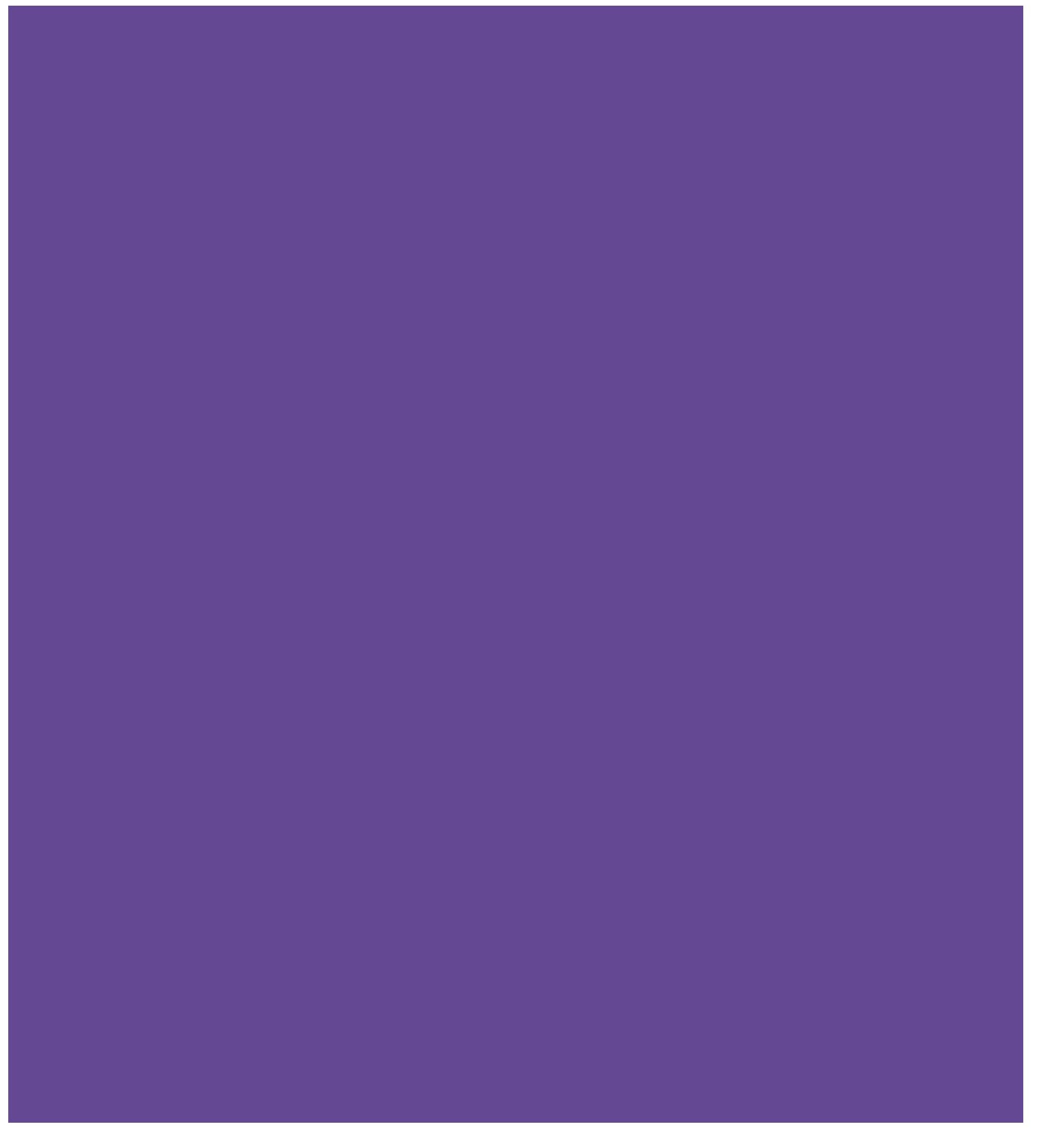




\section{RAFEINDATIEKK}

VERKEFNI 8

VERKEFNI 9 


\section{VERKEFNI 8 \\ KANNIĐ HVAĐA EFNI ERU Í RAFEINDATAEKJUM OG HVAĐ VERĐUR UM PAU AD NOTKUN LOKINNI}

\section{INNGANGUR}

Við framleiðslu á rafeindatækjum eru notuð̃ mörg mismunandi efni, oft fleiri en eitt hundrað talsins. Framleiðsla á rafeindatækjum er mjög flókið ferli. Í ferlið parf fjölmörg hráefni og mikla orku.

pað parf um pað bil 75 kíló af hráefnum til að framleiða einn farsíma. Megnið af hráefnunum eru eingöngu notuð við framleið̌slu símans og eru pví ekki í honum fullgerðum. Annars yrð̌i hann að sjálfsögðu býsna pungur.

Pegar hráefni eru unnin í pau efni sem til parf, er notuð̃ mikil orka.

Orkuna parf til að knýja vélar, bræða efni og við flutning á hlutum.

\section{VERKEFNI}

Athugið hvaða efni eru að öllu jöfnu notuð í rafeindatæki og skráið á blað hvaða efni petta eru. pið getið byrjað á að skoða farsímann ykkar í skólastofunni.
Líklega sjáið pið fljótt að meira en helmingur farsímans er gerður úr plasti.

Hvaða önnur efni haldið pið að séu í farsímanum?

Til glöggvunar getið pið skoðað teikninguna og séð hvaða efni eru venjulega notuð í rafeindatæki eins og farsíma. Kannski pekkið pið einhver pessara efna?

Hvernig á að með̌höndla úrgang úr rafeindatækjum og raftækjum?

Hvaða efni haldið pið að hægt sé að endurnýta eða endurvinna?

Ræddu við bekkjarfélaga pína um hvaða hráefni eru notuð til að framleiða mismunandi efni. 


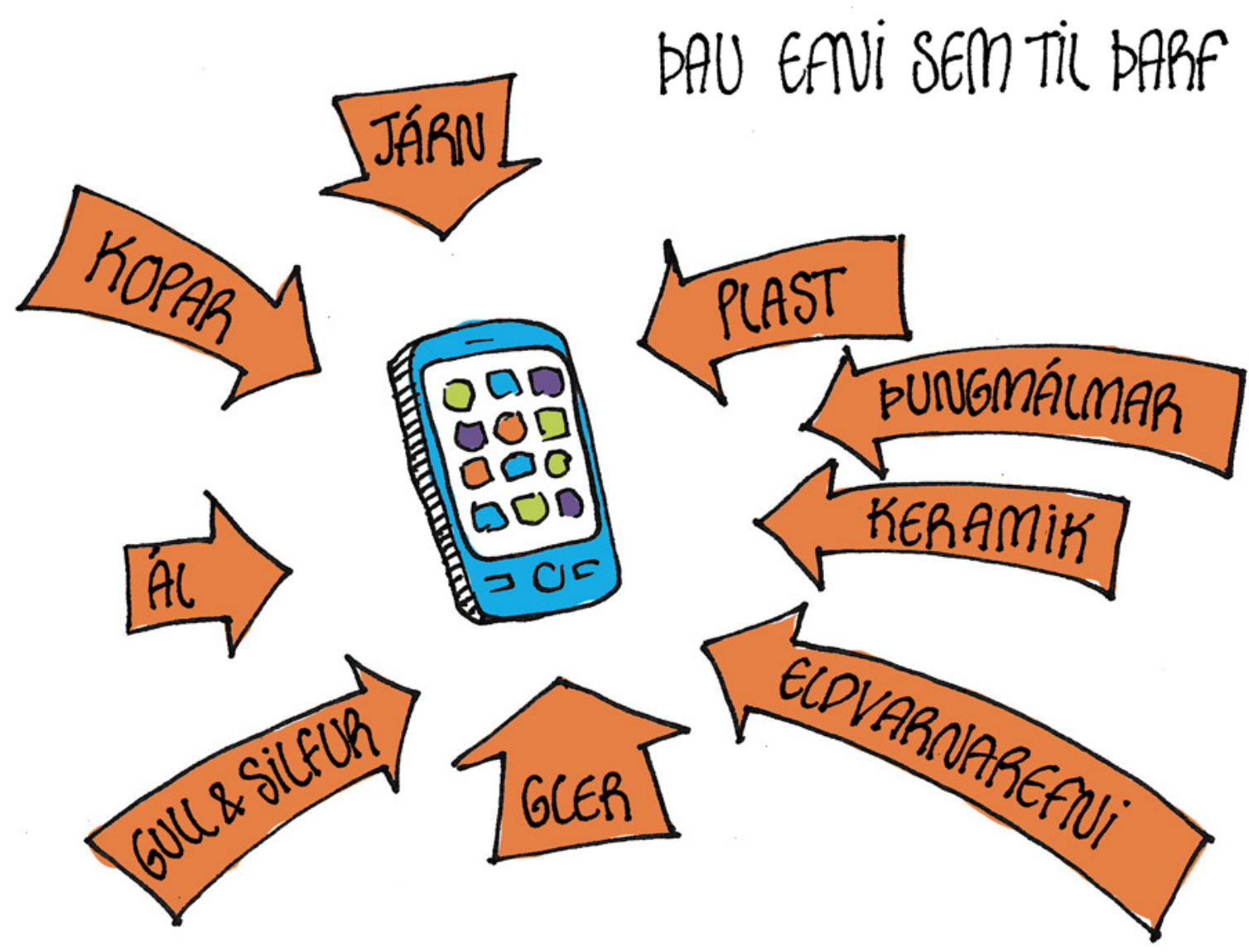

\section{VEIST PÚ?}

Meðal peirra málma sem er að finna í farsímanum pínum eru: Járn, kopar, ál, tin, sink, blý, nikkel, gull, silfur og platína.

Rafhlöður innihalda málma sem eru í vökva inni i rafhlöðunni. Pað eru málmarnir sem gera pað að verkum að rafhlaðan myndar rafstraum.

pað er auðvelt að aðskilja málmana hvern frá öðrum og endurvinna pá.

Áður var leyfilegt að henda rafhlöðum í ruslið en nú verður að koma öllum rafhlöðum til endurvinnslustöðva til endurvinnslu. 


\section{UPPLÝSINGAR UM AĐFÖNG OG HRÁEFNI Í RAFEINDATAKI}

\begin{tabular}{|c|c|c|c|}
\hline $\begin{array}{l}\text { Auzlindir/ } \\
\text { efni }\end{array}$ & Hráefni/orka & Eiginleikar & Umhverfi/endurvinnsla \\
\hline Plast & $\begin{array}{l}\text { Plast er framleitt úr } \\
\text { olíu. Pað parf u.p.b. } \\
2 \mathrm{~kg} \text { af olíu til að } \\
\text { framleiða } 1 \mathrm{~kg} \text { af } \\
\text { plasti. }\end{array}$ & $\begin{array}{l}\text { Til eru margar gerðir plastefna } \\
\text { sem notuð eru á mismunandi } \\
\text { hátt. Komast má svo að orði } \\
\text { að í plastfölskyldunni séu } \\
\text { búsundir mismunandi efna } \\
\text { sem hvert hefur sinn eiginleika. }\end{array}$ & $\begin{array}{l}\text { Hægt er að endurvinna plast } \\
\text { ef pað er hreint. pað er að } \\
\text { segja án matarafganga, } \\
\text { sápu og eiturefna. Til að } \\
\text { hægt sé að endurvinna } \\
\text { plast parf að flokka plastið } \\
\text { eftir plasttegundum. }\end{array}$ \\
\hline Keramik & $\begin{array}{l}\text { Keramik er unnið úr } \\
\text { leir og verður til við } \\
\text { brennslu leirsins. }\end{array}$ & $\begin{array}{l}\text { Leir er ekki vatnspéttur. } \\
\text { Yfirborð leirsins er oft pakið } \\
\text { með glerjungi úr keramik til } \\
\text { pess að fá vatnspétt yfirborð. }\end{array}$ & $\begin{array}{l}\text { Ekki er hægt að bræða } \\
\text { og endurvinna keramik. } \\
\text { Pess í stað er t. d. hægt að } \\
\text { endurnota mulið keramik } \\
\text { við byggingaframkvæmdir. }\end{array}$ \\
\hline Gler & $\begin{array}{l}\text { Gler er unnið úr } \\
\text { sandi. }\end{array}$ & $\begin{array}{l}\text { Gler er hægt að nota til margra } \\
\text { hluta. Рað er vatnspétt og } \\
\text { gegnsætt, en gler er brothætt. }\end{array}$ & $\begin{array}{l}\text { Gler er hægt að endurvinna } \\
\text { aftur og aftur. pað er gert } \\
\text { víða erlendis. }\end{array}$ \\
\hline Pungmálmar & $\begin{array}{l}\text { Pungmálmar eru } \\
\text { unnir úr hráefnum } \\
\text { úr námum víðsvegar } \\
\text { um heiminn. }\end{array}$ & $\begin{array}{l}\text { Pungmálmur er sá málmur } \\
\text { kallaður sem er eðlispyngri } \\
\text { en járn. Pungmálmar eru t.d. } \\
\text { kadmíum, blý, króm, kopar og } \\
\text { kvikasilfur. }\end{array}$ & $\begin{array}{l}\text { Pungmálmar eru hættulegir } \\
\text { mönnum og lífríkinu. } \\
\text { Pungmálmar eru eitruð efni, } \\
\text { jafnvel í litlu magni. Pau } \\
\text { safnast upp í líkamanum og } \\
\text { spilla heilsu og umhverfi. }\end{array}$ \\
\hline Eðalmálmar & $\begin{array}{l}\text { Eðalmálmar eru } \\
\text { unnir úr hráefnum } \\
\text { úr námum víðsvegar } \\
\text { um heiminn. }\end{array}$ & $\begin{array}{l}\text { Silfur, gull og platína eru } \\
\text { eðalmálmar sem henta vel til } \\
\text { að leiða rafmagn. Pess vegna } \\
\text { henta peir vel í rafeindatæki } \\
\text { með mörgum leiðslum. Gull er } \\
\text { algengt að nota í rafeindatæki. } \\
\text { pað er lagt í punnu lagi yfir } \\
\text { ódýrari málma. }\end{array}$ & $\begin{array}{l}\text { Gull, silfur og platínu } \\
\text { er hægt að endurvinna. } \\
\text { Rafeindatæki eru tekin } \\
\text { í sundur og gullið } \\
\text { endurunnið. par með } \\
\text { sparast gull, vatn og } \\
\text { orka. Pað minnkar pörf á } \\
\text { námagreftri í nýjum námum } \\
\text { sem eyðileggja landið. }\end{array}$ \\
\hline
\end{tabular}




\begin{tabular}{|c|c|c|c|}
\hline $\begin{array}{l}\text { Audlindir/ } \\
\text { efni }\end{array}$ & Hráefni/orka & Eiginleikar & Umhverfi/endurvinnsla \\
\hline Kopar & $\begin{array}{l}\text { Kopar er unninn með } \\
\text { námagreftri. }\end{array}$ & $\begin{array}{l}\text { Kopar er appelsínugulur } \\
\text { málmur. Kopar leiðir vel hita } \\
\text { og rafmagn og er oft notaður í } \\
\text { raflagnir. }\end{array}$ & $\begin{array}{l}\text { Kopar er hægt að } \\
\text { endurbræða og } \\
\text { endurnýta. Um pað bil } \\
1 / 3 \text { af koparpörfinni er } \\
\text { endurunninn kopar. Við } \\
\text { endurvinnslu á kopar } \\
\text { sparast } 60-90 \% \text { af peirri } \\
\text { orku sem annars pyrfti til } \\
\text { vinnslu úr námum. }\end{array}$ \\
\hline Ál & $\begin{array}{l}\text { Ál er unnið } \\
\text { úr sérstakri } \\
\text { jarðvegstegund. } \\
\text { (Mest notaða } \\
\text { hráefnið kallast } \\
\text { báxít) Við vinnsluna } \\
\text { er notuð mikil } \\
\text { raforka og mikill } \\
\text { úrgangur myndast. }\end{array}$ & $\begin{array}{l}\text { Ál er silfurhvítur málmur. Að } \\
\text { frátöldu járni er ál mest notaði } \\
\text { málmurinn. Ál ryðgar ekki. }\end{array}$ & $\begin{array}{l}\text { Við framleiðslu á einu kílói } \\
\text { af áli myndast } 85 \mathrm{~kg} \text { af } \\
\text { úrgangi. Við endurvinnslu á } \\
\text { áli myndast aðeins } 3,5 \mathrm{~kg} \text { af } \\
\text { úrgangi svo sparnaðurinn er } \\
\text { afar mikill. }\end{array}$ \\
\hline Járn & $\begin{array}{l}\text { Megnið af pví } \\
\text { járngrýti sem járn } \\
\text { er unnið úr fæst } \\
\text { með námavinnslu } \\
\text { neðanjarðar. }\end{array}$ & $\begin{array}{l}\text { Auðvelt er að aðgreina járn } \\
\text { frá öðrum hlutum pví járn er } \\
\text { segulmagnað. }\end{array}$ & $\begin{array}{l}\text { Járn er hægt að endurvinna } \\
\text { ef pað er rétt flokkað. Með } \\
\text { pví að endurvinna járn } \\
\text { og stál sparast meira en } \\
\text { helmingur peirrar orku } \\
\text { sem farið hefði í að vinna } \\
\text { járn úr hráefnum beint úr } \\
\text { náttúrunni. }\end{array}$ \\
\hline
\end{tabular}

Eldvarnarefni $\quad$ Til eru um 40

mismunandi efni

sem notur eru til að koma í veg fyrir

bruna. Pessi efni eru kölluð brómeruð eldvarnarefni.
Brómeruð eldvarnarefni eru höfð i plasti í rafeindatækjum til að fyrirbyggja íkveikju. Einnig er hægt að nota brómeruð eldvarnarefni í áklæði á sófa til pess að draga úr brunahættu.
Nokkur pessara brómeruðu eldvarnarefna hafa tilhneygingu til að safnast upp í lífkeðjunni og hafa skaðleg áhrif á umhverfi og heilsu. 


\section{VERKEFNI 9 \\ HVERNIG GETUM VIĐ FYRIRBYGGT MYNDUN ÚRGANGS VIĐ NOTKUN RAFEINDATAKJA?}

\section{INNGANGUR}

Rafeindatæki ganga fyrir rafstraumi pegar við notum pau. En pau geta líka purft rafstraum pó að̌ slökkt sé á peim. Sum rafeindatæki eru sett í samband við innstungu til að fá rafstraum en önnur fá rafstraum úr rafhlöðum.

Við̃ notum rafhlöour í marga hluti. Til dæmis i síma, ljós, myndavélar, leikföng og vasareiknivélar. Ef viơ notum ekki endurhlað̌anlegar rafhlöður myndast úrgangur pegar orkan er búin af rafhlöðunum og við fleygjum peim. pað leynast einnig rafhlöður í armbandsúrum, póstkortum með tónlist, sokkum með hljóði, skóm eða hárspennum með ljósi, dúkkum, böngsum og öðrum leikföngum sem lýsa eða gefa frá sér hljóð.

\section{VERKEFNI}

Athugið raftæki heima hjá ykkur.

Skrifið lista yfir rafeindatæki á heimilinu.

Hvaða hlutum gætir pú helst verið án ef draga pyrfti úr rafmagnsnotkun?

\section{VEIST PÚ?}

Eins og málum er nú háttað fara mörg efni forgörðum vegna pess hvernig við meðhöndlum úrgang.

Til dæmis er meira gull að finna á urðunarstöðum en í náttúrulegum gullnámum.

Í einungis fórum farsímum er nægilegt silfur í einn silfurhring.

\section{VEIST PÚ?}

Mikið sparast ef pú getur notað rafeindatæki lengur. Í hvert skipti sem búinn er til nýr farsími sem vegur 120 grömm myndast um 75 kíló af úrgangi áður en síminn lendir í vasa pínum. Pennan úrgang getur pú komið í veg fyrir í hvert skipti sem pú kaupir ekki nýjan farsíma. 
Hvaða rafeindatæki eru algeng á flestum heimilum?

Hver haldið pið að próunin verði á heimilum í framtíðinni varðandi fjölda hluta sem ganga fyrir rafmagni?

Er góð hugmynd að nota endurhlaðanlegar rafhlöður?

Úrgangur frá rafeindatækjum myndast pegar pau eru framleidd, pegar pau eru flutt milli landa, pegar pau eru notuð og pegar pau hafa lokið hlutverki sínu og er ekki lengur pörf.

Hve oft eru keypt ný rafeindatæki á pínu heimili? Hversu oft er pað í samanburð̌ við heimili bekkjarfélaga pinna?

Hvernig heldur pú og bekkjarfélagar pínir að best sé að̀ standa að pví að draga úr rafeindatækjaúrgangi?

Hvað eigum við að gera við rafeindatæki pegar pau eru úr sér gengin og á að̌ henda?

Hvernig getum við lengt líftíma rafeindatækja?

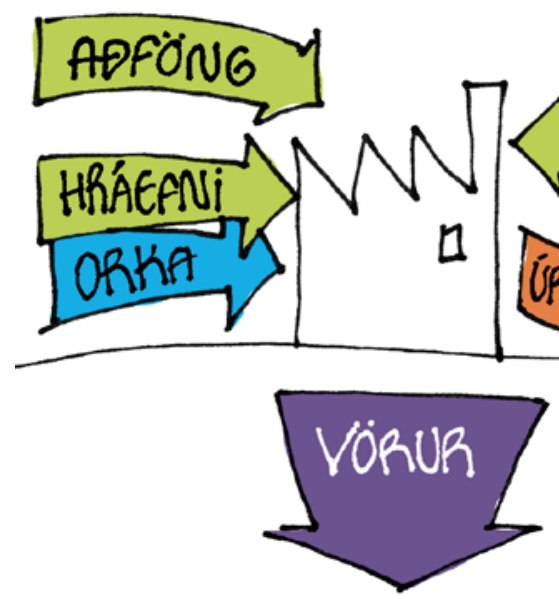

Af stað með úrgangsforvarnir - Nemendahefti

ISBN 978-92-893-3999-5 (PRINT)

ISBN 978-92-893-4000-7 (PDF)

http://dx.doi.org/10.6027/US2015-403

US 2015:403

๑) Norræna ráðherranefndin 2015

Höfundar Tomas Sander Poulsen og Anja Charlotte Gylling, PlanMiljø og Søren Breiting, DPU.

Útlitshönnun: Koch\&Falk (DesignKonsortiet)

Myndskreyting: Mette Falk

Leturgerð: Meta

pýðing og staðfærsla: Steinn Kárason/Landvernd

petta kennsluefni er gefið út með styrk frá Norrænu ráðherranefndinni. Innihald pessa bæklings endurspeglar ekki endilega skoðanir Norrænu ráðherranefndarinnar, stefnu eða tilmæli.

www.norden.org/nordpub

Norrænt samstarf

Norrænt samstarf er eitt umfangsmesta svæðasamstarf í veröldinni. Pátttökulöndin eru Danmörk, Finnland, Ísland, Noregur, Svípjóð, Færeyjar, Grænland og Álandseyjar.

Norrænt samstarf á sér pólitískar, efnahagslegar og menningarlegar rætur og gegnir mikilvægu hlutverki í evrópsku og alpjóðlegu samstarfi. Norrænu samstarfi er ætlað að efla styrk Norðurlanda í styrkri Evrópu.

Norrænt samstarf miðar að pví að efla og styrkja norræna og svæðisbundna hagsmuni og gildi í albjóðlegu umhverfi. Sameiginlegir hagsmunir landanna stuðla að pví að styrkja stöðu Norðurlanda alpjóðlega sem forysturíkja í nýsköpun og samkeppnishæfni.

\section{Norræna ráðherranefndin}

Ved Stranden 18

1061 København K

Danmörku

Sími (+45) 33960200

www.norden.org 


\section{U1) norden}

Norræna ráðherranefndin 2015

Ved Stranden 18

1061 København K

Danmörku

Sími (+45) 33960200

www.norden.org

Umhverfis- og auðlindaráðuneytið

Skuggasundi 1,

150 Reykjavík, sími: 5458696

www.umhverfisraduneyti.is

Landvernd pórunnartúni 6,

105 Reykjavík,

sími 5525242

www.landvernd.is

US 2015:403

ISBN 978-92-893-3999-5 (PRINT)

ISBN 978-92-893-4000-7 (PDF)

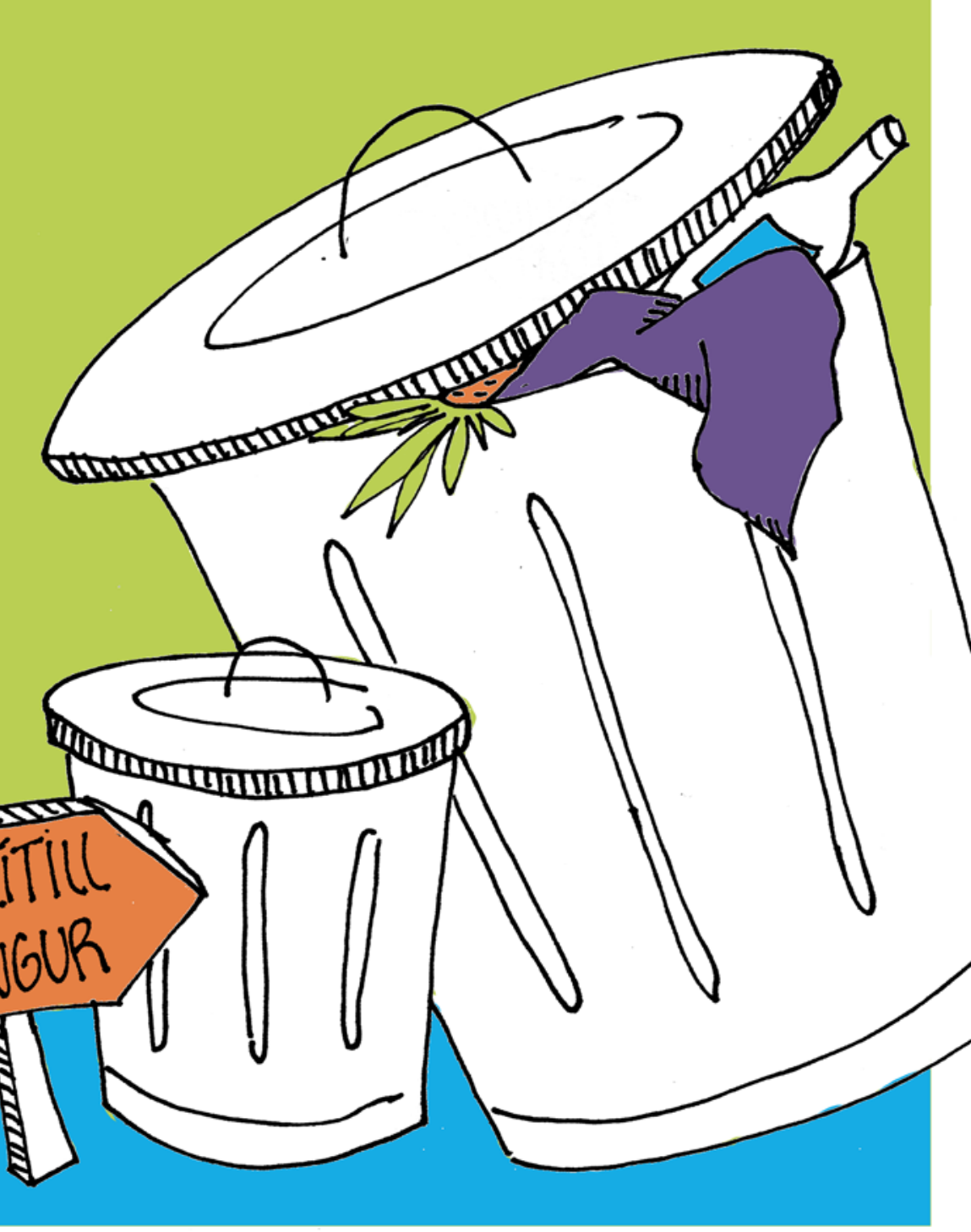

